\title{
Bilgi Paylaşımını Etkileyen Faktörlerin Bilgi Paylaşımı Üzerine Etkisi: Bir Alan Araştırması
}

DOI: $10.26466 /$ opus.632192

\author{
Mihriban Hatunoğlu* - Salih Yeşil** \\ * Yüksek Lisans Öğr., KSÜ Sosyal Bilimler Enstitüsü, Kahramanmaraş / Türkiye \\ E-Posta: mihribanhatunoglu@hotmail.com ORCID: 0000-0002-0123-1543 \\ ** Prof. Dr., Kahramanmaraş Sütçü İmam Üniversitesi, İ̈BF Kahramanmaraş / Türkiye \\ E-Posta: syes66@hotmail.com \\ ORCID: 0000-0003-3237-2258
}

\begin{abstract}
Öz
İşletmelerde bilgi paylaşımı, yönetim sürecinin en önemli unsurlarından biri haline gelmiştir. Bilgi paylaşımı, çalışanların ihtiyaç duydukları bilgiye en hızlı ve en kolay bir şekilde ulaşmalarını sağlamaya dönük süreçlerin tümü olarak tanımlanabilmektedir. Bilgi paylaşımı işletmelerin başarısı üzerinde büyük etkiye sahiptir. Bu nedenle işletmelerde bilgi paylaşımına büyük önem verilmektedir. Buradan yola çıkarak, bu makale, bilgi paylaşımını etkileyen faktörleri ele alan bir çalışma olmuştur. Bu çalışmanın temel amacı, bilgi paylaşımını etkileyen faktörlerin bilgi paylaşımı üzerindeki etkilerini belirlemektir. Bu amaçla öncelikle konuya ilişkin yerli ve yabancı literatür taranarak kavramsal çerçeve ve hipotezler oluşturulmuştur. Daha sonra, çalışma alan çalışması ile desteklenmiş̧tir. Araştırmanin hipotezleri SPSS istatistik programından elde edilen sonuçlar ile analiz edilmiştir. Çalışmada yapılan analizler sonucunda bilgi paylaşımın etkileyen faktörlerden sadece pozitif bilgi paylaşım normları ve ortak amacın bilgi paylaşımı (açık ve kapalı bilgi paylaşımı) üzerinde pozitif etkisi olduğ u belirlenmiştir. Elde edilen bulgularm ilgili literatüre bundan sonra yapılacak çalışmalara ve konunun gelişimine katkı sağlayacă̆ı beklenmektedir. Araştırmanın sonuç kısmında elde edilen bulgular teorik ve uygulama bağlamında tartışılmıştır.
\end{abstract}

Anahtar Kelimeler: Bilgi, Bilgi Paylaşımı, Bilgi Paylaşımını Etkileyen Faktörler. 


\title{
The Effects of Factors Influencing Knowledge Sharing on The Knowledge Sharing: A Field Research
}

\begin{abstract}
Knowledge sharing in companies is very important part of managerial process. Information sharing can be defined as all processes to ensure that employees reach the information they need in the fastest and easiest way. Knowledge sharing in companies has an impact on the success of the companies. Because of this fact, companies take knowledge sharing very important. Starting from this point of view this article concentrates on the factors influencing on knowledge sharing. The main purpose of this study is to determine the factors affecting on knowledge sharing. For that purpose, the conceptual framework and hypothesis were formed by reviewing literature on the subject. Next, a field study was carried out. Research hypotheses were tested by analyzing the obtained data with SPSS software. As a result of the analysis in the study only pro-sharing norms and shared vision of knowledge sharing factors have a positive effect on knowledge sharing (Explicit and tacit knowledge sharing). It is expected that the finding from this study will contribute the current literature and future investigations and development of the concept. The findings from this study have also been discussed both theoretically and practically in the result section.
\end{abstract}

Keywords: Knowledge, Knowlede Sharing, Factors Influencing Knowledge Sharing. 


\section{Giriş}

Yirmi birinci yüzyılın uluslararası iş dünyası, şirketler için sadece yeni fırsatlar sunmamış aynı zamanda yeni tehditlerde meydana getirmiştir. Önceden birbirleriyle kıyasıya rekabet halinde olan şirketler artık pazarlama, satış, dağıtım vb. birimlerinin birçok aşamasında artan bir şekilde birlikte çalışma gayreti gösterdikleri gözlemlenmiştir (Koza, 2008, s.10). Buna bağlı olarakta son yıllarda bilgi ve bilgi paylaşımı kavramlarına olan ilgide artış dikkat çekmektedir. Bilgi bireyin zihninde varlığını gösteren bilişsel ve aynı zamanda fizyolojik bir olgudur (Laudon ve Laudon, 2011, s.417). Günümüz toplumlarının öncelikli hedefi, bilgi toplumu seviyesine ulaşabilmektir (Demircan ve Moltay, 1997, s.1). Bu toplum küresel bilgi ekonomisinin getirdiği değişim ile birlikte bilgi ve iletişim teknolojilerinden yararlanarak bilgiyi yaratma, kullanma, saklama, paylaşma vb. yani bilgiyi yönetme yoluna girmiştir (Öztürk, 2005, s.8). Bilgi yönetimi bilgiye sahip olmaktan ziyade bilgiyi nasıl kullanacağını bilmekle ilgilenir. Bu anlayışta önemli olan ise neyi bilip neyi bilmediğimiz olmayıp, bildiklerimizden nasıl en fazla verim alabileceğimizdir (Koza, 2008, s.10). Bilgi yönetilerek bilgiden beklenenden daha fazla yarar sağlanabilmektedir. Hızla gelişen ve değişen dünyada bilgi yönetimi hakkındaki çalışmalar bilgi teknolojileri üzerine yoğunlaşırken, artık bu çalışmalar daha da indirgenerek bilginin sahibi olan bireyleri ele almaktadır. Rekabet ortamında bilgi teknolojilerinin taklit edilmesi veya rakipler tarafından kolayca kopyalanması, bilgi yönetimi çalışmalarının insan odaklı olmasını gerekli kılmıştır. Çalışanların ise bilginin peşinde koşması için işletmenin çalışanlar tarafından paylaşımcı bir yer olarak alg1lanması gerekir. Bu ise işletmede paylaşımc bir iklimin oluşturulmasının gerekliliğini beraberinde getirir.

İşletmelerde başarı için bilginin var olması tek başına yeterli olmayıp, aynı zamanda etkin kullanımı da gereklidir. Bilginin etkin kullanımı bilgi yönetimi sayesinde olmaktadır. Bilgi yönetiminin elemanlarından olan bilgi paylaşımı bilginin işletmeler, ekipler veya insanlar arasında basit bir şekilde ulaşılması, transfer edilmesi, taşınması için gösterilen tüm faaliyetleri içermektedir (Kalling ve Styhre, 2003, s.135). Burada, bilgi paylaşımını etkileyen unsurlar öne çıkmaktadır. Bilgi paylaşımı bütün işletmenin katılımı ile gerçekleşen bir süreç olarak karşımıza çıkmaktadır. Ayrıca, işletmenin payla- 
şımı destekleyen bir yer haline getirilmesiyle olur. Bilgi paylaşımı ortamı oluşturulurken bilgi paylaşımını etkileyen faktörlerin iyi belirlenmesi gerekmektedir. Bilginin ve kaynakların paylaşılmasının gerekliliğine ve yaratıcılı̆ga vurgu yapan normlar bireyleri alanlarında geliştirirken işletmeleri de ileriye taşımış olacaktır. Böyle bir ortamın sağlanmasında bilgi paylaşımını etkileyen faktörlerin önemini yadsımamak gerekir.

Organizasyonlarda iş görenler tarafından bir davranış, işletme yönetimi sürecinde bir faaliyet ve bilgi yönetiminin bir basamağı olarak görülen bilgi paylaşımını etkileyen çeşitli faktörlerin varlığından söz etmek mümkündür (İçöz, 2014, s.49). Bilgi paylaşımını etkileyen faktörler ayrıntılı bir şekilde ortaya konmalıdır daha sonra sonuçlar ışığında bilgi paylaşımını arttıran yollar analiz edilmelidir. Bu çalışmada bilgi paylaşımı ve etkileyen faktörler üzerinde durulmuştur. Çalışmanın amacı bilgi paylaşımını etkileyen faktörlerin bilgi paylaşımı üzerindeki etkisini belirlemektir.

Uluslararası literatüre baktığımızda bilgi paylaşımını etkileyen faktörler üzerine çeşitli çalışmalara rastlamak mümkündür. Yapılan çalışmalarda bilgi paylaşımını etkileyen faktörler olarak motivasyon, örgütsel adalet, kültür, örgütsel iletişim, örgütsel güven, yenilikçi davranış, yeni bilgiyi öğrenme, uygulama becerisi, kaynak güvenilirliği, yönetici ve lider, örgüt yapısı, bireysel faktörler, örgütsel faktörler, teknolojik faktörler ve yapısal engeller, bilginin doğası şeklinde sınıflandırıldığı görülmüştür (Demirel ve Seçkin, 2011; Ipe, 2003; Öneren ve diğ., 2016; Kwok ve Gao 2005). Yapılan çalışmalar daha çok bütün faktörler yerine tek faktör (Işı1k, 2018; Demirel ve Seçkin, 2011; Holste, 2010; Lin, 2007), ikili faktörler (Lin, 2006; Wang ve Wang, 2012; Hau ve diğerleri, 2013), üçlü faktörler (Chiu, 2006; Öneren ve diğerleri, 2016), dörtlü değişkenler (Göç, 2012), yedili değişkenler (Erden, 2016) şeklinde ele alınarak bilgi paylaşımı üzerindeki etkileri araştıılmıştır. $\mathrm{Bu}$ çalışmamızda ise bir bütün olarak on faktör birlikte ele alınmış ve bu faktörler ilgili alan yazında daha önce az çalışılmış olanlar arasından seçilmiştir. Bu faktörler şunlardır; Diğerkâmlık, karşılıklılık, öz yeterlilik, güven, öz farkındalık, örgütsel ödül, pozitif bilgi paylaşım normları, kimlik, ortak amaç ve son olarakta ortak dildir.

Literatüre sektörel bazda bakıldığında bu alandaki önceki çalışmaların genel olarak mobilya sektöründe (Öneren ve diğ., 2016), tekstil sektöründe (Yeniçeri ve Demirel, 2007), ilaç sektöründe (Demirel ve Seçkin, 2011), turizm sektöründe yer alan konaklama işletmelerinde (Ayazlar, 2012) ve eği- 
tim sektöründe yer alan özel üniversitelerde (Yaghi ve diğerleri, 2011) yürütüldüğüne rastlanılmıştır. Daha önceki çalışmalara bakıldığında kamu sektöründe daha az çalışma yapıldığı gözlemlenmektedir. Bu kapsamda, araştırma Kahramanmaraş ilinde bir kamu kurumunda yürütülmüştür. Alan çalışması anket yöntemiyle desteklenmiştir. Anket çalışmasında, daha önceki farklı çalışmalarda geçerlilik ve güvenilirliği test edilmiş ölçekler kullanılmıştır. Elde edilen veriler SPSS 22.0 istatistiksel veri analizi programı kullanılarak teorik ve uygulama bağlamında tartışılmıştır.

\section{Kavramsal Çerçeve}

\section{Bilgi}

Günümüze kadar bilginin tanımı birçok akademisyen, araştırmacı ve uzman tarafından çeşitli şekillerde ifade edilmiştir. Bunlardan bazıları şöyledir; Bilgi genel anlamda deneyim, uzmanlık enformasyon ve yetenek olarak ifade edilebilir. Bilgi aynı zamanda bir duygu hali, süreç, nesne veya yeterlik olarakta ele alınabilir. Bilgi yalnızca bir olgunun nasıl yapılacağını bilmekle ilgili değildir. Aynı zamanda bir olgunun kim tarafından, nerede, nasıl, ne zaman ve neden yapıldığını bilmekle de alakalıdır (Cho ve diğerleri, 2011). Bilgi, bireyin beynindedir ve hayat boyu deneyimledikleri ve öğrendiklerinin toplamıdır (Barutçugit, 2002, s.58). Bilgiye dayalı bir ekonomide, bilgi, şirketler ve uluslar için rekabet yeteneğinin ve büyümenin temel şeklidir (Lin, 2007). Bilgiyi kaynağına göre açık bilgi (explicit knowledge) ve kapalı bilgi (tacit knowledge) şeklinde iki grupta incelemek mümkündür.

Açık Bilgi: Açık bilgi (Explicit knowledge), "sayıları ve diyagramları içeren, açık bir dille bir araya getirilmiş anlamlı enformasyon kümesidir" (Nonaka ve diğerleri, 1996 s.205). Başka bir tanımda, açk bilgi, rakamlardan ve/veya kelimelerden oluşmaktadır. Yani, işletme tarafından kolay bir şekilde ulaşlır özelliktedir. Bu tür bilgiler her işletmenin ulaşabileceği enformasyonlardır (Koza, 2008, s.231). Açık bilgi kişisel değildir, kaydedilebilir, ulaşılabilir, anlaşılabilirdir ve gerektiğinde kâğıda aktarılıp arşivlenir. Ayrıca, açık bilgi, düşünce aktarımı yoluyla ya da kendi kendine kitap okuma yoluyla paylaşılarak sağlanan bilgidir (Lim ve diğ., 1999, s.616). Resimlerle, kelimelerle veya farklı araçlarla anlattı̆̆ımız bilgidir (Barutçugil, 2002, s.63). 
Kapalı Bilgi: Kapalı bilgi (Implicit knowledge), kökleşmiş mental modelleri, inançları ve perspektifleri içerir ve bu yüzden açı bir şekilde ifade etmek pek kolay değildir (Nonaka, 1996, s.98). Zihnimizde, bünyemizde her yere götürdüğümüz bilgi türüne örtülü bilgi denir (Barutçugil, 2002, s.63). Kapalı bilgi bir şeyin açık bir şekilde ifade edilmeden anlaşılmasıdır ya da kelimelerine sahip olmadığımız bilgilerdir. Kapalı bilgi otomatiktir. Düşünmeden kullanılır ya da düşünmek için çok az zaman gerektirir (Smith, 2001, s.314).

Bilginin elde edilmesi, toplanması, üretilmesi, düzenlenmesi, depolanması, paylaşılması, uygulanması, değerlendirilmesi, kullanılması, aktarılması gibi süreçler bilgi yönetimi sayesinde oluşmaktadır. Bilgi yönetimini en sade şekilde tanımlayacak olursak bilgiyi oluşturmak, geliştirmek ve paylaşmak için uygulanacak yeni yollardır (Barutçugil, 2002, s.49). Bilgi yönetimi, kayıtlı veya kayıt dışı örgüt verilerini ve kişisel tecrübe ve bilgiye dayalı birikimleri toplayıp, düzenleyip, kayıt edip, faydalı bilgi haline dönüştürerek bu bilgileri doğru zamanda, doğru kişilere, gerek duyulan her yerden ulaşılabilmesini sağlayıp, örgütün entelektüel birikimini arttırmak, tekrar edilen işlem ve süreçlerin tamamının teknolojik araç ve gereçlerle gerçekleşmesini sağlamak ve bunun neticesinde pozitif iş sonuçları sağlamak amaciyla uygulanan kültürel ve teknolojik işlemler dizisidir (Koza, 2008, s.225-27). İşletme başarısını arttırmayı amaçlayarak bilginin elde edilmesi, kullanılması, paylaşılması ve geliştirilmesinin tamamını bilgi yönetimi kavramı karşılamaktadır (Barutçugil, 2002). Bilgi yönetimi bilgiye sahip olmaktan ziyade bilgiyi nasıl kullanacağını bilmekle ilgilenir. Bu anlayışta önemli olan ise neyi bilip neyi bilmediğimiz olmayıp, bildiklerimizden nasıl en fazla verim alabileceğimizdir (Koza, 2008, s.10). Bilgi paylaşımı, bilgi yönetiminin en önemli açlarından biri olarak görülür (Gupta ve diğ., 2000). Benzer bir şekilde Wang ve Noe (2010) bilgi yönetimi girişimlerinin başar1sında bilgi paylaşımının çok önemli bir rol oynadığını belirtmiştir. Bilgi paylaşımı iş alanlarında bilgi yaratmanın ve elde etmenin önemli bir yöntemidir (Xinyan ve Xin, 2006, s.876).

\section{Bilgi Paylaşımı}

Literatürde çeşitli yazarlar tarafından bilgi paylaşımı kavramı farklı şekillerde tanımlanmıştır. Bu tanımlamalardan bazıları şu şekildedir: 
- Bilgi paylaşımı, elde edilen tecrübenin ve bilginin, işletmenin farklı birimleri arasında, şimdiki ve gelecekteki çıkarları için alış-verişine olanak sağlayan ekip davranışıdır (Chow ve Chan, 2008: 458; Lin 2008: 1508; Davenport ve Prusak, 2001).

- Bilginin yayılması olarakta betimlenen bilgi paylaşımı olgusu çeşitli kaynaklardan sağlanan enformasyon ve bilginin paylaşımının ve değişiminin oluşturulduğu bir süreci anlatır (Huber, 1991, s.88).

- Bilgi paylaşım, bilgi gereksinimini sezmek, sistematik ve teknik altyapıyı oluşturmak ve bilgiye gereksinim duyan diğer bireyler için ulaşılabilir hale getirmek anlamına gelmektedir (Seonghee, 2008, s.282).

- Bilgi paylaşımı, çalışanların ihtiyaç duydukları bilgiye en hızlı ve en kolay bir şekilde ulaşmalarını sağlamaya dönük süreçlerin tümü olarak tanımlanabilir (Zaim, 2006).

- Connelly ve Kelloway (2001, s.294-301) bilginin el değiştirmesi ve diğerlerine yardım etme eylemlerinden oluşan bir takım çalışması olarak bilgi paylaşımını tanımlamıştır.

- Bilgi paylaşımı kavramında, bireysel ya da ekip olarak başkaları ile birlikte çalışmak ve bu durumdan ortak bir çıkar sağlamak için kişilerin istekli davranmaları gerekir. Çalışanlar yüksek düzeyde ortak bir tutum göstermezler ise bilgi paylaşımının örgütlerde gerçekleşmesi mümkün değildir (Barutçugil, 2004, s.115). İlgili alan yazında farklı bilgi paylaşımı türlerine rastlamak mümkündür. Bilgi paylaşımını açık ve kapalı bilgi paylaşımı olarak sınıflandırmıştır. Bunlardan kısaca bahsetmek gerekirse;

Açık Bilgi Paylaşımı: Açık bilgi paylaşımı (Explicit knowledge sharing) depolanabilen, saklanabilen, belgelenebilen ve kodlanan her türlü bilginin dağıtılmasını ve iletilmesini kapsar (Nonaka ve diğ., 2002). Açık bilgi paylaşımı niyeti daha ucuz olan (yani daha az pahalı olan) bir kaynağın paylaşımı olarak algılanır ki bu da daha pahalı kaynak paylaşımı olan kapalı bilgi paylaşımını etkilemektedir (Reychav ve Weisberg, 2010, s.289). Açk bilgi paylaşımı kurumsallaşmış işletmelerde bilgi paylaşımının neredeyse tüm biçimlerini oluşturur. İşletmelerde açık bilgi paylaşımı uygulamaları kolay elde edilir, kodlanır ve iletilir olduğundan daha yaygın görülür. Prosedür, 
resmi dil, kılavuzlar, bilgi teknolojileri sistemleri gibi yönetim mekanizmaları çalışanların açık bilgi paylaşımına olan isteğini yükseltir (Wang ve Wang, 2012, s.8900).

Kapalı Bilgi Paylaşımı: Kapalı bilgi paylaşımı (Implicit knowledge sharing) sözel olmayan yani sezgisel olan paylaşım çeşididir. Kapalı bilgi paylaşımı sosyal ilişkilerin ve davranışların içinde gömülüdür (Becerra ve diğerleri, 2008, s.693). Kapalı bilgi paylaşımı genellikle gönderici ve alıcı arasında yakınlık gerektirir (Roberts, 2000, s.434). Kapalı bilgi kişiseldir ve sosyal etkileşim aracilığıyla paylaşılır (Aydıntan ve diğerleri, 2010, s.17). Çalışan örtük bilgiyi, işletmeye rekabet ortamında yüksek potansiyele sahip başarı katarak işletmeyi ileriye taşıdığı bilgi olarak algılar (Reychav ve Weisberg, 2010, s.290). Yüz yüze etkileşim ilk olarak kapalı bilgi paylaşımı anlamına gelmektedir. Kapalı bilgi paylaşımının anahtarı isteklilik ve bireylerin bildiklerini ve öğrendiklerini paylaşma kapasitesidir (Wang ve Wang, 2012, s.8900).

\section{Bilgi Paylaşımın Etkileyen Faktörler}

Bilgi paylaşımı, kişilerin başka kişilerle veya işletmeyle olan bağlarını belirleyen bütün etmenlerden etkilenmektedir (Erşahan, 2011, s.266). Konu ile ilgili alan yazına bakıldığında bilgi paylaşımını etkileyen faktörler örgüt kültürü (Vaas, 1999; Zaim, 2005), örgütsel iletişim (Işık, 2002; Tutar, 2003), bilgi teknolojileri (Odyakmaz, 2000; Yıldız ve Yılmazer, 2005), motivasyon (Zaim, 2005) vb. gibi bir takım faktör ile birlikte ele alınmıştır. Diğer çalışmalardan farklı olarak bu çalışmada ele alınan bilgi paylaşımını etkileyen faktörler; diğerkâmlık, karşılıklılık, öz yeterlilik, güven, öz farkındalık, örgütsel ödül, pozitif bilgi paylaşım normları, kimlik, ortak amaç ve ortak dil kavramlarıdır. Bunlar kısaca şu şekilde özetlenmektedir.

Diğerkâmlık: Başkalarına yardım etmekten zevk almak diğerkâmlık kavramından gelmektedir. Diğerkâmlık, insanlar başkalarına yardım etmekten zevk aldıklarında ve bu davranışlarından dolayı hiçbir karşııık beklemediklerinde var olmaktadır (Smith, 1981). Sosyal fedakârlık anlamına da gelen diğerkâmlık literatürde özgecilik, fedakârlık, yardımseverlik kelimeleri ile de karşılık bulmaktadır. Çalışanların bariz bir şekilde diğer çalışanlara 
ve/veya üstlerine performanslarını arttırmaya yönelik yardım etmesidir (Çetin, 2004, s.21). Diğerkâmlık, kısaca herkesten çok diğer çalışanlara yardım eden kişilerin davranışları diğerkâmlık olarak adlandırılır (Ünal, 2003, s.18). Yardımlaşma eylemi yalnızca iş arkadaşlarına karşı olmayıp; aynı zamanda tedarikçilere, müşterilere de gösterilebilmektedir. Destek olmaya sebep olan davranışın direkt örgütü ilgilendiren bir konu olmaması diğerkâmlık boyutunda ele alınmasında en önemli nedendir (Organ, 1988, s.559).

Karşılıklılık: Karşılıklılık, bireylerin başkalarına yardım etme sonucunda ilerde ne zaman karşılık alacaklarını hatta karşılık alıp alamayacaklarını bilmeden yardım etme hareketlerini sürdürmemeleri olarak tanımlanabilir (Molm ve diğerleri, 2000, s.1399). Bilgi paylaşımında bulunan bireyler bu davranışlarının yararlı olacağı beklentisini taşıdıklarında karşılıklılık meydana gelmiş olur (Schulz, 2001, s.661). Karş1lıkllık, bilgi değişiminin müşterek ve adil olarak uygulanması anlamına gelir (Chiu ve diğ., 2006, s.1877). Bir diğer ifade ile, her iki tarafın dürüst ve adil bilgi değişimine dahil olduğu bir ilişkidir (Tamjidyamcholo ve diğ., 2013, s.226).

Öz Yeterlilik: Öz yeterlilik, bireyin performans sergilemesi için ihtiyaç duyduğu etkinlikleri düzenleyip uygun bir şekilde gerçekleştirme kapasitesidir (Ulusoy, 2015, s.62). Öz yeterlilik, bireylerin hayatlarındaki olayları kontrol altına almaları için ihtiyaç duydukları davranış şekli, motivasyon ve bilişsel kaynaklarını dahil edebilme yeteneğine olan inançlarıdır (Wood ve Bandura, 1989, s.361-364). Öz yeterlilik, insanların sahip oldukları yetenekler ile neler yapabilecekleri algısıyla bağlantılıdır. Öz yeterlilik bilgi paylaşanların işle alakalı sorunları çözmede iş verimliliğini arttırmada ya da işletmelerine fark katma konusunda onların bilgisinin işletmeye yardımcı olduğuna inandıklarını gösterir (Kollock, 1999). Öz yeterlilik inancı, yardımcı olabilecek ya da engelleyecek düşünde tarzının oluşmasını sağlar. Burada öz yeterliliği sağlam olan birey kendisi için daha yüksek hedefler koyar ve koyduğu hedeflere bağlılığı daha fazla olur (Bandura ve Cervone, 1986).

Güven: Güven fikir ve düşüncelerin değişiminin devam etmesini sağlar ve mükemmel bir bilgi değişimi ile ilerler (Tamjidyamcholo ve diğ., 2013, 
s.225). Güven bilgi paylaşımı tarafından bakıldığında, işletmeye, gruba ve çalışanlara olan inanma isteğidir. Başkalarının bizden beklentilerine karşı empati kurduğumuzda karşılıklı etkileşim ile paylaşım davranışı ilerler (Renzl, 2008, s.207).

Öz Farkındalık: Öz farkındalık, Çalışanların bilgi paylaşımı davranışları iş arkadaşları ve üsleri tarafından fark edilme arzularını gerçekleştirmelerinin en iyi yoludur (O'Dell ve Grayson, 1998). İş çevrelerinde, bilgiye katkı sağlayan bireyler diğerlerine sahip oldukları değerli tecrübelerini ve bilgilerini göstererek fayda sağlayabilmektedirler (Ba ve diğerleri, 2001, s. 230). Bu durum onlara saygı duyulmasını sağlarken aynı zamanda daha iyi bir imaj çizmelerine olanak tanımaktadır (Constant ve diğerleri, 1996, s. 120). Buna bağlı olarak, bilgiye katkı sağlayan bireyler bilgi paylaşırken benlik algılarını geliştirerek (yani kendini algılama, öz-kavram) fayda sağlamış olmaktadırlar (Hall, 2001). Yüksek kalitede teknik bilgi sağlayan insanlar iş yerinde daha iyi prestij sağlamaktadırlar ve bu durumdan da memnun olmaktadırlar (Kollock, 1999).

Örgütsel Ödül: Çalışan, yapması gereken işlerde başarılı performans gösterdiği takdirde örgüt tarafından iş görene maddi ve manevi sunulan kazanımlara örgütsel ödül denilmektedir (Sarıkaya, 2014, s. 24). Bilgi paylaşım sürecini etkileyen faktörlerden biri de gerçek ve algılanan ödüllerdir. Örgütlerde, teknoloji odaklı bilgi paylaşan iş görenleri teşvik etmek ve cesaretlendirmek için ödüllendirme sisteminde gelişmelerin oluşturulması şeklindeki bulgular bilgi paylaşımı ve örgütsel ödül arasındaki ilişkiyi desteklemektedir (Gupta ve Govindarajan, 2000, s. 77). Örgütsel ödül çalışan davranışı ile organizasyonların çalışanlardan beklentileri arasındaki açığı en aza indirir (Christensen, 2005, s.18). Örgütsel ödül sistemi, bilgi paylaşım sürecini etkilemektedir. Ödül, çalışana verilen ücretten daha büyük bir anlama gelmektedir. Bilgi paylaşımının daha yaygın hale gelmesi amaçlanıyorsa, örgüt içerisindeki başarılar ödüllendirme planı ile teşvik edilmelidir (Nemli, 2007, s.84).

Pozitif Bilgi Paylaşım Normları: Güçlü bir grup çalışması, iş birliği ve dayanışma normlarının olduğu yerlerde, diğer üyelerde olduğu gibi insanlar gereken çabayı göstermekten rahatsız olmayacaklardır. Bu durumun tersi- 
ne, zayıf pozitif bilgi paylaşım normlarının oluştuğu durumlarda, bilgi paylaşanlar çaba gerektiren kodlanmış bilgileri (yani kapalı bilgiler) saklamaya eğilim göstereceklerdir. Bu yüzden, pozitif bilgi paylaşım normları zayıf olduğunda bilgi paylaşanlar kodlama yoluyla bilgilerine erişimi engellemiş veya kısıtlamış olacaklardır. Ayrıca, kodlama çabası bilgi paylaşan bireylerin kimliklerini negatif olarak etkileyebilmektedir (Kankanhalli ve diğ., 2005, s.120).

Kimlik: Kimlik, bir kişinin sahip olduğu özelliklerini tanıması anlamına gelmektedir. Bireyler diğer kişi ya da grup üyelerini tanımaya çalıştığı gibi kendinin farkına vardığı süreçtir (Bagozzi, 2002, s.11). Kimlik, bireylerin aidiyet duygusu ve sanal topluluklara karşı pozitif hissetmelerine işaret etmektedir (Chiu ve diğerleri, 2006, s.1877). Çalışanların menfaatleri ve işletmenin menfaati birleştiğinde kimlik güçlü hale gelmektedir. Güçlü kimliğin olduğu durumlarda insanlar örgütün bilgi deposuna katkı sağlayabilirler. Diğer taraftan, zayıf kimlikler örgütün bilgi deposuna katkıda bulunmak için yüksek motivasyona ihtiyaç duyabilirler (Kanhanhalli ve diğerleri, 2005, s.121).

Ortak Amaç: Ortak amaç, kolektif hedefleri ve işletmenin üyelerinin istek veya arzularını bünyesinde barındırır. Bir ortak amaç, işletmenin farklı birimlerini birbirine bağlar veya kaynakları birleştirir. Aynı amacı paylaşan işletme üyeleri kaynak alışverişinde veya paylaşımında arkadaşça olmaya daha yatkın olacaklardır (Tsai ve Ghoshal, 1998). Ortak amaçlar, ilgiler ve vizyonlar bilgi paylaşımını anlamlı kılar. Bu da bilgi paylaşım kalitesini ve miktarını arttırır (Chiu ve diğerleri, 2006, s.1880). Ortak amaç ve sosyal ağ bilgi paylaşımıyla ilgili davranışları ve kişisel normları direkt olarak etkilemektedir (Chow ve Chan, 2008, s.464).

Ortak Dil: Ortak dil katılımcların birbirlerini anlayabilmelerini ve ortak çalışma alanı inşa etmelerini sağlar. Bu açıdan, ortak dil sadece fikirlerin paylaşılmasına yardımcı olmaz aynı zamanda benzer geçmişe sahip olanlarda ya da benzer tecrübeleri yaşayanlarda etkili bir iletişim sağlar. Bu yüzden, ortak dil bilgi paylaşımı aktivitesine dahil olmada bireyleri motive edecek ve paylaşılan bilginin kalitesinin yükseltilmesinde rol oynayacaktır 
(Chiu ve diğ., 2006, s.1878). Ortak dil fikirleri ve kavramları bünyesine alır ki bu da dilin kendisinden daha kapsamlıdır. Ortak dil ve kodlar davranışlara ve hareketlere cevap vermede önemli bir rol oynar. Bilgi paylaşım sürecini destekler (Tamjidyamcholo ve diğ., 2013, s.226). Ortak dil dilin kendisinin ötesindedir. Paylaşılan kodlar ve dil toplu hedefleri ortak bir şekilde anlamayı kolaylaştırır ve harekete geçmek için uygun yolları sunar (Chiu ve diğ., 2006, s.1878).

\section{Araştırmanın Değişkenleri Arasındaki İlişkiler ve Hipotezler}

Bilgi paylaşımını etkileyen faktörler ile bilgi paylaşımı arasındaki ilişki ve bu ilişkiye yönelik hipotezler aşağıda açıklanmaktadır.

Diğerkâmlık ve Bilgi Paylaşımı İlişkisi: Çalışanlar, bilgi paylaşımına dahil olurken zevk alıyorlarsa ve bunu eğlenerek yapıyorlarsa işletme içindeki bilgi paylaşımı bu durumdan etkilenir. Buradan yola çıkarak, diğerkamlık içsel bir motive edici faktör olarak bilgi paylaşımını çoğaltmaktadır (Hau ve diğ., 2013, s.358). Bu doğrultuda Hau ve diğerleri, (2013) yapmış olduğu araştırmalara göre, diğerkâmlığın açk ve kapalı bilgi paylaşımı üzerinde önemli bir etkisi olduğu sonucuna ulaşmışlardır. Wasko ve Faraj (2005) bilgiye katkı sağlayan bireylerin diğerkâmlık davranışı göstererek tatmin olduklarını belirtmiştir. Açıklanan bilgiler doğrultusunda oluşturulan hipotezler şu şekildedir:

H1: "Diğerkâmlık açık bilgi paylaşımını pozitif yönde etkiler."

H2: "Diğerkâmlık kapalı bilgi paylaşımını pozitif yönde etkiler."

Karşılıklılık ve Bilgi Paylaşımı İlişkisi: Karşılıklılık, bireylerin başkalarına yardım etme sonucunda ilerde ne zaman karşılık alacaklarını hatta karşılık alıp alamayacaklarını bilmeden yardım etme hareketlerini sürdürmemeleri olarak tanımlanabilir (Molm ve diğ., 2000, s.1399). Bilgi paylaşımı güçlü bir karşlıklılık duygusu içerir (Wasko ve Faraj, 2005). Karşlıklılı̆̆ın bilgi paylaşımı üzerine etkilerini belirlemek isteyen bir araştırma sonuçlarına göre, Hau ve diğerleri, (2013) karşılıklılık her iki bilgi paylaşım türüyle (açık ve kapalı bilgi paylaşımı) önemli ölçüde ilişkilidir. Bir diğer çalışmaya göre ise, karşl1ıklılı̆̆ın, bireylerin bilgi paylaşım niyeti üzerinde önemli bir etkisi 
olduğu sonucuna varılmıştır (Tamjidyamcholo ve diğ., 2013, s.228). Açıklanan bilgiler ışığında oluşturulan hipotezler şu şekildedir:

H3:"Karşıllklllık açık bilgi paylaşımın pozitif yönde etkiler."

H4:"Karşıllklılık kapalı bilgi paylaşımın pozitif yönde etkiler."

Öz Yeterlilik ve Bilgi Paylaşımı İlişkisi: Öz yeterlilik, kendi kendini denetlemenin bir çeşitidir. Öz yeterlilik bir kişinin çaba ve gayretlerini arttırır. Ayrıca zorluk ve engellerle karşılaştığında tahammül gücünü de arttırmasını sağlar (Tamjidyamcholo ve diğ., 2013, s.224). Öz yeterlilik bilgi paylaş1mına motive eden temel bir faktör olarak görülür. Wasko ve Faraj (2005) çalışanları iş arkadaşlarıyla bilgi paylaşımına motive eden bir faktör olarak tanımlamaktadır. Araştırmalarına göre, yüksek öz güveni olan bireylerin değerli olan bilgiyi sağlama yeteneğinin de yüksek olduğunu ortaya çkarmıştır. Açıkanan bilgiler doğrultusunda oluşturulan hipotezler şu şekildedir:

H5: "Öz yeterlilik açı bilgi paylaşımını pozitif yönde etkiler."

H6:"Öz yeterlilik kapalı bilgi paylaşımını pozitif yönde etkiler."

Güven ve Bilgi Paylaşımı İlişkisi: Bilgi değişiminde güvenin önemi vardır. Bireyler arası ilişkilerde güvenin varlığı yüksek ortak anlayış seviyesinde paylaşım yeteneği gösterilmesini sağlar. Sosyal ve kültürel kavramlarda gelişen güven ve ortak anlayış kavramlarının her ikisi başarılı bilgi paylaşımının ön koşuludur (Roberts, 2000, s.435). Güven bilgi paylaşımının önemli bir öncülüdür. Genellikle değerlerin, normların ve prensiplerin bir birleşimi olarak görülen güven, bilgi paylaşımını arttırmaktadır. Bundan dolayı, yüksek seviyede güven, bilgi paylaşımının artmasına yol açacaktır (Chang ve Chuang, 2011, s.10). Bir diğer çalışmaya göre, güven bireylerin bilgi paylaşımı niyetini önemli ölçüde etkiler (Tamjidyamcholo ve diğerleri, 2013, s.228). Belirtilen bilgiler kapsamında oluşturulan hipotezler şu şekildedir:

H7: "Güven açık bilgi paylaşımını pozitif yönde etkiler."

H8: "Güven kapalı bilgi paylaşımını pozitif yönde etkiler."

Öz Farkındalık ve Bilgi Paylaşımı İlişkisi: Öz farkındalık kısaca şu şekilde tanımlanmaktadır. Çalışanların bilgi paylaşımı davranışları iş arkadaşları ve üsleri tarafından fark edilme arzularını gerçekleştirme çabalarıdır ( $\mathrm{O}^{\prime}$ Dell ve 
Grayson, 1998). Yüksek kalitede teknik bilgi sağlayan insanlar iş yerinde daha iyi prestij sağlamaktadırlar ve bu durumdan da memnun olmaktadırlar (Kollock, 1999). Belirtilen bilgiler doğrultusunda oluşturulan hipotezler şu şekildedir:

H9:"Öz farkındalık açı bilgi paylaşımını pozitif yönde etkiler."

H10:"Öz farkındalık kapalı bilgi paylaşımını pozitif yönde etkiler."

Örgütsel Ödül ve Bilgi Paylaşımı İlişkisi: Örgütsel ödüller dış kaynaklıdır ve çalışanların algısı daha çok parasal ödüllerle tatmin olursa bilgi paylaşımı davranışı gözlemlenebilir (Hung ve diğ., 2011, s.418). Hau ve diğerleri, (2013, s.358)'nin yapmış olduğu araştırmalar sonucuna göre örgütsel ödüllerin açık bilgi paylaşımı niyeti üzerinde önemli bir etkisi olduğuna ulaşmışlardır. Anlatılan bilgiler ışığında oluşturulan hipotezler şu şekildedir:

H11:"Örgütsel ödül açık bilgi paylaşımın pozitif yönde etkiler."

H12:"Örgütsel ödül kapalı bilgi paylaşımını pozitif yönde etkiler."

Pozitif Bilgi Paylaşım Normları ve Bilgi Paylaşımı İlişkisi: Güçlü bir grup çalışması, iş birliği ve dayanışma normlarının olduğu yerlerde, diğer üyelerde olduğu gibi insanlar gereken çabayı göstermekten rahatsız olmayacaklardır (Kankanhalli ve diğ., 2005, s.120). Bu durumun tersine, zayıf pozitif bilgi paylaşım normlarının görüldüğü durumlarda, bilgi paylaşanlar çaba gerektiren kodlanmış bilgileri (yani örtük bilgiler) saklamaya eğilim göstereceklerdir. Bu yüzden, pozitif bilgi paylaşım normları zayıf olduğunda bilgi paylaşanlar kodlama yoluyla bilgilerine erişimi engellemiş veya kısitlamış olacaklardır. Ayrıca, kodlama çabası bilgi paylaşan bireylerin kimliklerini negatif olarak etkileyebilmektedir (Kankanhalli ve diğ., 2005, s.120). Açılanan bilgiler kapsamında oluşturulan hipotezler şu şekildedir: ler."

H13:"Pozitif bilgi paylaşım normları açık bilgi paylaşımını pozitif yönde etki-

H14:"Pozitif bilgi paylaşım normları kapalı bilgi paylaşımını pozitif yönde etkiler."

Kimlik ve Bilgi Paylaşımı İlişkisi: Kimlik kavramı, bir kişinin sahip olduğu özelliklerini tanıması anlamına gelmektedir. Kimlik, bireylerin aidiyet duygusuna işaret etmektedir. Aynı zamanda motivasyondan ve bilgi değişi- 
minden etkilenen bir harekettir (Chiu ve diğ., 2006, s.1877). Açıklanan bilgiler doğrultusunda oluşturulan hipotezler şu şekildedir:

H15:"Kimlik açık bilgi paylaşımını pozitif yönde etkiler."

H16:"Kimlik kapalı bilgi paylaşımını pozitif yönde etkiler."

Ortak Amaç ve Bilgi Paylaşımı İlişkisi: Ortak amaç, işletmenin farklı birimlerini birbirine bağlar veya kaynakları birleştirir. Aynı amacı paylaşan işletme üyeleri kaynak alışverişinde veya paylaşımında arkadaşça olmaya daha yatkın olacaklardır (Tsai ve Ghoshal, 1998). Ortak değerler ve amaçlar insan topluluklarını ve ağların bir araya getirir, iş birlikçi eylemleri sağlar ve son olarakta daha iyi nicelik ve nitelikte bilgi temin ederek işletmeye fayda ve kar sağlar. Ortak amaçlar, ilgiler ve vizyonlar bilgi paylaşımını anlamlı kılar. Bu da bilgi paylaşımı kalitesini ve miktarını arttırır (Chiu ve diğ., 2006, s.1880). Ele alınan bilgiler kapsamında oluşturulan hipotezler şu şekildedir:

H17:"Ortak amaç açık bilgi paylaşımını pozitif yönde etkiler."

H18:"Ortak amaç kapalı bilgi paylaşımını pozitif yönde etkiler."

Ortak Dil ve Bilgi Paylaşımı İlişkisi: Ortak dil dilin kendisinin ötesindedir, akronime, zekâya ve günden güne etkileşimleri birbiriyle ilişkilendiren tahminlere işaret eder. Paylaşılan kodlar ve dil toplu hedefleri ortak bir şekilde anlamayı kolaylaştırır ve harekete geçmek için uygun yolları sunar (Chiu ve diğ., 2006, s.1878). Algıyı kolaylaştıran ortak dil, kişilerarası anlaşmayı kolaylaştırmaktadır. Bunun nedeni ise, birbirlerinden hangi bilgiyi alıp hangi bilgiyi almadıklarını bilmelerinden kaynaklanmaktadır (Chang ve Chuang, 2011, s.11). Beklentilerinin zittına Chiu ve diğerleri, (2006)'nin yapmış olduğu çalışmalar sonucu ortak dilin bilgi paylaşımı miktarını önemli derecede etkilemediği ortaya çıkmıştır. Açılanan bilgiler ışı̆̆ında oluşturulan hipotezler şu şekildedir:

H19:"Ortak dil açık bilgi paylaşımını pozitif yönde etkiler."

H20: "Ortak dil kapalı bilgi paylaşımını pozitif yönde etkiler."

Yukarıda bilgi paylaşımını etkileyen faktörlerin bilgi paylaşımı üzerinde etkisini incelemek üzere oluşturulan çalışmanın hipotezleri doğrultusunda oluşturulan model aşağıda Şekil 1'de gösterilmiştir. 


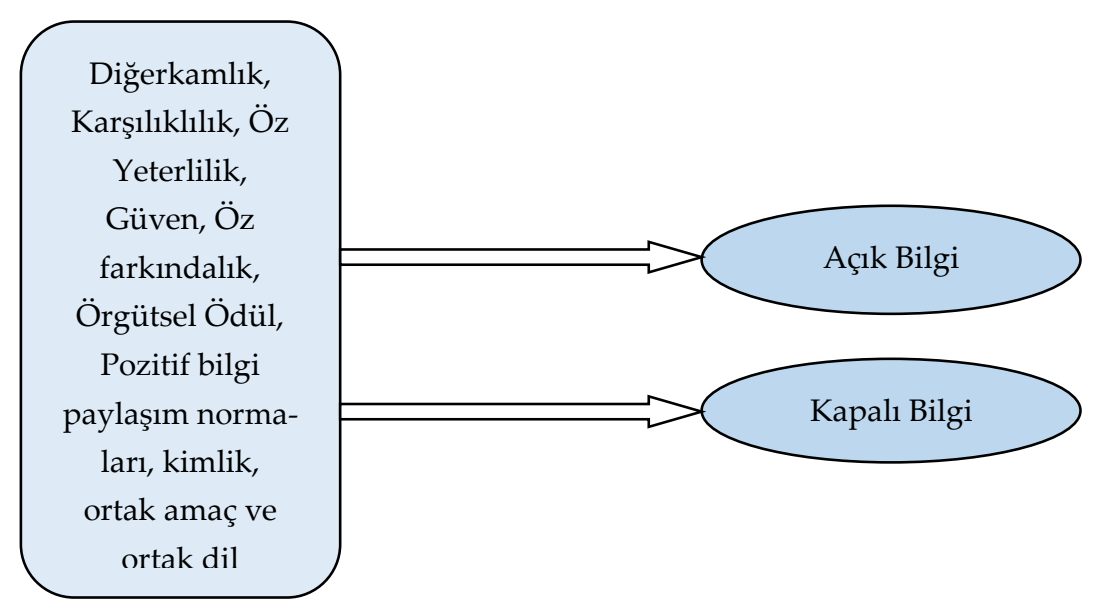

Şekil 1. Araştırmanın Modeli

\section{Yöntem}

\section{Araştırmanın Amacı ve Önemi}

Bilgi paylaşımı kavramı ülkemizde son dönemlerde gittikçe önemi artan bir konu haline geldiği düşünülmektedir. Bu yüzden çalışmasının amacı bilgi paylaşımını etkileyen faktörlerin bilgi paylaşımı üzerindeki etkisini belirlemektir.

İlgili alan yazına baktığımızda, bilgi paylaşımı konusu genel olarak motivasyon, örgütsel adalet, kültür, yenilikçi davranış, yeni bilgiyi öğrenme, uygulama becerisi, kaynak güvenilirliği, yönetici ve lider, örgüt yapısı, bireysel faktörler, örgütsel faktörler, teknolojik faktörler ve yapısal engeller gibi konularla birlikte ele alınmıştır. Bu çalışmada ise bilgi paylaşımını etkileyen diğerkâmlık, karşılıklılık, öz yeterlilik, güven, öz farkındalık, örgütsel ödül, pozitif bilgi paylaşım normları, kimlik, ortak amaç ve ortak dil değişkenleri ele alınmıştır. Örgütler için böyle önemli olan bilgi paylaşımı konusu bugüne kadar mobilya sektöründe, tekstil sektöründe, ilaç sektöründe ve turizm sektöründe yer alan işletmelerde incelenmiştir. Yapılan literatür taraması sonucunda, bilgi paylaşımı konusunun ağırlıklı olarak özel sektörde ele alındığı fark edilmiştir. Kamu sektöründe bu konuyu ele alan çalış- 
maya az rastlanılmıştır. Buradan hareketle çalışma kamu sektöründe yürütülmüştür. Bu durum çalışmamınız önem ve değerini ortaya koymakla kalmayıp aynı zamanda elde edilecek sonuçların bilgi paylaşımı literatürüne önemli katkılar sağlayacağı da düşünülmektedir. Bu çalışma bir alan çalışması ile desteklenerek yukarıda belirtilen amaçlara ulaşılmaya çalışılmiştır.

\section{Araştırmanın Evreni ve Örneklemi}

Araştırmanın evren büyüklügüünü Kahramanmaraş ilinde faaliyet gösteren bir kamu kurumunun yaklaşık 400 çalışanı oluşturmaktadır. Araştırmada veri toplama yöntemi olarak anket kullanılmıştır. Araştırmada kullanılan ölçekler daha önceki çalışmalardan alınmıştır. Anketler çalışanlara elden teslim edilmiştir. Gönüllü̈lük esasına göre anketör firma tarafından dağıtılmış ve toplanmıştır. Yaklaşık 250 çalışandan dönüş sağlanmıştır.

Anketin uygulanması sonucunda elde edilen bilgiler SPSS (Statistical Package for Social Sciences) programına giriş yapılmıştır. Veri girişi esnasında meydana gelebilecek hatalar, yanlışlıklar kontrol edilmiş, eksik ve hatalı kayıtlar düzenlenerek, hatasız kayıt sağlanmıştır. Çalışmanın amaçlarına ulaşmak için güvenilirlik, frekans, korelasyon ve regresyon analizlerinden faydalanılmıştır.

Araştırma Kahramanmaraş Sütçü İmam Üniversitesi Araştırma Projeleri tarafından desteklenmiş olup BAP (Bilimsel Araştırma Projesi) kapsamında aracı anketör şirket tarafından Kahramanmaraş ilinde faaliyet gösteren bir kamu kurumu çalışanlarına elden dağıtılmış ve toplanmıştır.

\section{Araştırmada Kullanılan Ölçekler}

Ankette araştırma modelinde yer alan değişkenlere ilişkin literatürde geçerliliği ve güvenilirliği onaylanmış ölçekler yer almaktadır. Çalışanlarının bilgi paylaşımı davranışlarını ölçen dört adet ölçek düzenlenmiştir. Anketin birinci kısmı, katılımcların sosyo-demografik bilgilerini öğrenmeye yönelik olup "cinsiyet, medeni durum, yaş, eğitim düzeyi, gelir düzeyi, kurumdaki toplam çalışma süresi, ünvan, memleket" soruları ilave edilmiştir. Anketin diğer bölümlerinde yer alan önermeler 5'li Likert ölçeği (1=kesinlikle katıl- 
miyorum, 2=katılmiyorum, 3=kararsızım, 4=katıliyorum ve 5=kesinlikle katılıyorum) ile değerlendirilmiştir. Ankette, araştırma modelinde yer alan on adet değişkene ayrıca açı ve kapalı bilgi paylaşımına ilişkin literatürde geçerliliği ve güvenilirliği onaylanmış ölçeklere yer verilmişir. Bu ölçekler aşağıda Tablo 1'de gösterilmiştir.

Tablo 1. Araştırmada Kullanılan Ölçekler

\begin{tabular}{lcc}
\hline FAKTÖR & SORU SAYISI & KAYNAK \\
\hline Diğerkâmlık & 4 & \\
Karşılıklılık & 4 & Kankanhalli ve diğerleri, (2005, \\
Öz Yeterlilik & 4 & s. 141) \\
Güven & 4 & \\
Öz Farkındalık & 5 & \\
Örgütsel Ödül & 4 & Chiu ve diğerleri, (2006, s. 1879) \\
Pozitif Bilgi Paylaşım Normları & 6 & Reychav ve Weisberg (2010, s. \\
\hline Kimlik & 4 & 300) \\
Ortak Amaç & 3 & \\
Ortak Dil & 3 & \\
\hline Açık Bilgi Paylaşımı & 4 & \\
Kapalı Bilgi Paylaşımı & 6 & \\
\hline
\end{tabular}

\section{Araştırmanın Stnırlılikları}

Her çalışmada olduğu gibi, bu çalışmanın da bazı sınırlılıkları bulunmaktadır. İlk olarak, belli bir kurum ve sektörde sınırlı katılım ile gerçekleştirilmiş olan bu çalışmanın sonuçlarını genellemek zorlaşmaktadır. Bu nedenle araştırma, belli bir sektörün belli bir iş hacminde çalışan bireylerin fikirlerini yansitan bulgulara sahiptir. Okuyuculara araştırma farklı sektörlerde yürütüldüğünde sonuçların değişeceği olasılığını dikkate almalarını öneririz. Buna ek olarak lokal çalışmaların yürütüldüğü uygulamalarda kültürel farklılıkların etkisinden söz etmek mümkündür. Bu perspektiften ele alındığında, ileride gerçekleştirilecek olan çalışmaların daha geniş katılımlı olması, daha fazla kurum ve sektörü içine alması araştırma sonuçlarının genelleştirilmesi ve karşılaştııılması açısından büyük önem taşımaktadır. Diğer taraftan ileride yapılacak olan çalışmalara farklı değişkenler eklenerek ve çalışmada farklı veri toplama yöntemleri kullanılarak daha geniş kapsamlı sonuçlar elde edilebilir. Bunların yanında uzun dönemli çalışmalar daha derinlemesine bilgi elde etme noktasında önem taşımaktadır. Bu çalışmada toplanan verilerin güvenilirliği ve geçerliliği veri toplamada kulla- 
nılan anket tekniğinin özellikleri ve ankete katılanların verdikleri cevapların gerçekliği ile sınırlı kalmaktadır.

\section{Bulgular}

\section{Katılımcıların Demografik Analizi ve Sonuçları}

Araştırma örnekleminin demografik değişkenlere göre dağılımlarına ilişkin frekans ve yüzdeler aşağıdaki Tablo 2' de sırasıyla sunulmuştur.

Ankete katılan çalışanların cinsiyet özelliklerine baktığımızda, katılan 250 kişiden 190'ının (\%76) kadın, 60'ının (\%24) ise erkek olduğu gözlemlenmiştir. Buna göre katılımcıların çoğunluğunun kadın olduğu anlaşılmaktadir.

Ankete katılan çalışanların medeni durumlarına baktığımızda katılımc1lardan 193 kişinin $(\% 77,2)$ evli, 57 kişinin (\%22,8) bekâr olduğu sonucuna ulaşılmıştır. Buna göre, evlilerin oranının bekârlardan fazla olduğu söylenebilir.

Araştırmadan elde edilen verilere göre ankete katılanlardan sadece 1 kişi $(\%, 4)$ 20-24 yaş aralığında, 57 kişi $(\% 22,8)$ 25-29 yaş aralığında, 118 kişi $(\% 47,2) 35-39$ yaş aralığında ve 74 kişi $(\% 29,6) 40$ yaş ve üzeri yaşlardadır.

Katılımclların eğitim düzeylerine göre dağılımında, 109 kişi $(\% 43,6)$ lise mezunu, 84 kişi $(\% 33,6)$ ön lisans mezunu, 56 kişi $(\% 22,4)$ lisans mezunu ve 1 kişi $(\%, 4)$ yüksek lisans mezunu bireylerden oluşmaktadır. Tabloya baktığımızda çalışanların çoğunluklu olarak lise veya ön lisans mezunu olduğu görülmektedir.

Anket çalışmamıza katılan çalışanların gelir düzeylerine baktığımızda 23 kişi $(\% 9,2)$ 1500-2400 TL arası, 65 kişi (\%26) 2500-3400 TL arası, 131 kişi (\%52,4) 3500-4400 TL arası, 31 kişi (\%12,4) 4500-5400 TL aras1, olduğu görülmektedir. Buna göre, ankete katılan çalışanların yarısından fazlası (\%52,4'lik oranla) 3500-4400 TL arası aylık kazanç sağladıkları söylenebilir. 
Tablo 2. Katılımcıların Demografik Özellikleri

\begin{tabular}{|c|c|c|c|}
\hline & & Frekans & Yüzde \\
\hline \multirow[t]{2}{*}{ Cinsiyet } & Kadın & 190 & 76 \\
\hline & Erkek & 60 & 24 \\
\hline \multirow[t]{2}{*}{ Medeni Durum } & Evli & 193 & 77,2 \\
\hline & Bekar & 57 & 22,8 \\
\hline \multirow[t]{4}{*}{ Yaş } & $20-24$ & 1 & 4 \\
\hline & $25-29$ & 57 & 22,8 \\
\hline & $35-39$ & 118 & 47,2 \\
\hline & 40 ve üstü & 74 & 29,6 \\
\hline \multirow[t]{4}{*}{ Eğitim Düzeyi } & Lise & 109 & 43,6 \\
\hline & Ön Lisans & 84 & 33,6 \\
\hline & Lisans & 56 & 22,4 \\
\hline & Yüksek Lisans & 1 &, 4 \\
\hline \multirow[t]{4}{*}{ Gelir Düzeyi } & $1500-2400$ & 23 & 9,2 \\
\hline & $2500-3400$ & 65 & 26 \\
\hline & $3500-4400$ & 131 & 52,4 \\
\hline & $4500-5400$ & 31 & 12,4 \\
\hline Kurumdaki Toplam & $1-3$ yıl & 37 & 14,8 \\
\hline \multirow[t]{3}{*}{ Çalışma Süresi } & $4-6$ yıl & 51 & 20,4 \\
\hline & $7-9$ yıl & 121 & 48,4 \\
\hline & 10 yıl ve üstü & 41 & 16,4 \\
\hline \multirow[t]{5}{*}{ Ünvan } & Servis Sorumlusu & 1 & 4 \\
\hline & Şef & 8 & 3,2 \\
\hline & Memur & 232 & 91,9 \\
\hline & Veri Hazırlama ve & 9 & 3,6 \\
\hline & Kontrol İşletmeni & & \\
\hline \multirow[t]{3}{*}{ Memleket } & Kahramanmaraş & 115 & 46 \\
\hline & Diğer & 135 & 54 \\
\hline & Toplam & 250 & 100 \\
\hline
\end{tabular}

Ankete katılan çalışanların kurumdaki çalışma sürelerine baktı̆̆ımızda 37 kişi $(\% 14,8)$ 1-3 yıl arası, 51 kişi (\%20,4) 4-6 yıl arası, 121 kişi (\%48,4) 7-9 yıl arası ve 41 kişi $(\% 16,4) 10$ yıl ve üzeri çalışma sürelerinin olduğu görülmektedir. Buna göre katılımcıların kurumdaki çalışma süreleri en çok 7-9 yıl arası olduğu söylenebilir.

Araştırmadan elde edilen verilere göre ankete katılanların ünvanlarına bakıldığında sadece 1 kişi $(\%, 4)$ servis sorumlusudur, 8 kişi $(\% 3,2)$ şeftir, 232 kişi $(\% 91,9)$ memurdur, son olarakta, 9 kişi $(\% 3,6)$ veri hazırlama ve kontrol işletmenidir. Buna göre, katılımcıların çoğunluğunu memurların oluşturduğunu söyleyebiliriz.

Araştırmadan elde edilen verilere göre ankete katılanlardan 115 kişi (\%46) Kahramanmaraşlıdır, 135 kişi (\%54) farklı illerden katılımclardır. 


\section{Araştırmanın Temel Bulgularına İlişkin Analizler}

Bu başlık altında, araştırmada yer alan temel bulgulara ilişkin güvenilirlik, korelasyon ve regresyon analizlerine yer verilmiştir. Ayrıca bu analizlerin sonuçlarına yönelik bulgulara değinilmiştir.

Güvenilirlik Analizi Sonuçlarn: Güvenilirlik, bir test veya ankette bulunan soruların birbirleri ile tutarlılığını ve kullanılan ölçeğin ilgilenilen problemini ne kadar yansıttığı anlamına gelir (Kayış, 2010, s.403).

Tablo 3. Araştırmada Yer Alan Ölçeklere İlişkin Güvenilirlik Analizi Sonuçları

\begin{tabular}{lcc}
\hline Ölçekler & Soru Sayısı & Cronbach's Alpha \\
\hline Diğerkâmlık & 4 &, 746 \\
Karşılıklılık & 4 &, 738 \\
Öz Yeterlilik & 4 &, 731 \\
Güven & 4 &, 739 \\
Öz Farkındalık & 5 &, 724 \\
Örgütsel Ödül & 4 &, 737 \\
Pozitif Bilgi Paylaşım Normları & 6 &, 738 \\
Kimlik & 4 &, 745 \\
Ortak Amaç & 3 &, 727 \\
Ortak Dil & 3 &, 747 \\
Açı Bilgi Paylaşımı & 4 &, 734 \\
Kapalı Bilgi Paylaşımı & 6 &, 726 \\
\hline
\end{tabular}

Ölçek geliştirme ve uyarlama çalışmalarında iç tutarlılığın belirlenmesinde genellikle kullanılan bir güvenilirlik belirleme yöntemi olan Cronbach's Alpha değerinin ölçek çalışmalarında en az $\alpha=, 70$ veya üzerinde olması gerektiği genel kabul görmektedir (Seçer, 2015, s.179). Araştırmada kullanılan ölçeklerin güvenilirlik analizleri, iç tutarlılık Cronbach's Alpha katsayıların hesaplanması ile yapılmış, bu analize ait sonuçlar Tablo 3'te gösterilmiştir. Anket formunda sorulan bütün soruların güvenilirlik analizi yapılmıştır. Tüm soruların güvenilirlik analizi sonuçları aşağıdadır; Tablo 3'te açıkca gösterildiği gibi, uygulanan güvenilirlik analizi sonucunda diğerkâmlık, karşılıklılık, öz yeterlilik, güven, öz farkındalık, örgütsel ödül, pozitif bilgi paylaşım normları, kimlik, ortak amaç, ortak dil, açık bilgi paylaşımı ve kapalı bilgi paylaşımı değişkenlerinin Cronbach's Alpha değerleri 
,724 ile, 747 aralığında değişmektedir. Açıklanan bilgiler ışığında tüm değerlerin 0,70 üzerinde olduğu belirlenmiş ve güvenilirliği kabul edilmiştir.

Korelasyon Analizi ve Sonuçları: Çalışmanın hipotezlerini test etmek amacryla korelasyon analizleri yapılmış olup sonuçlar şu şekilde sıralanmıştır.

Aşağıda korelasyon analizi tablosunda Pearson korelasyon katsayıları ve anlamlılık düzeyleri görülmektedir. Tablo 4 bilgi paylaşımını etkileyen faktörlerin derecesi arasındaki ilişkiler açısından incelendiğinde;

- Karşılıklılık ( $\mathrm{r}=, 125 ; \mathrm{p}<0,05)$, öz farkındalık $(\mathrm{r}=, 128 ; \mathrm{p}<0,05)$, pozitif bilgi paylaşım normları $(\mathrm{r}=, 446 ; \mathrm{p}<0,01)$, kimlik $(\mathrm{r}=, 305 ; \mathrm{p}<0,01)$, ortak amaç $(\mathrm{r}=, 407 ; \mathrm{p}<0,01)$ ve ortak dil $(\mathrm{r}=, 191 ; \mathrm{p}<0,01)$ ile açık bilgi paylaşımı arasinda pozitif yönlü ve istatistiksel olarak anlamlı bir ilişki belirlenmiştir.

- Diğerkamlık ( $\mathrm{r}=, 031 ; \mathrm{p}>0,05)$, öz yeterlilik ( $\mathrm{r}=, 006$; $\mathrm{p}>0,05)$, güven ( $\mathrm{r}=, 024$; $\mathrm{p}>0,05)$ ve örgütsel ödül $(\mathrm{r}=, 064 ; \mathrm{p}>0,05)$ ile açık bilgi paylaşımı arasında istatistiksel olarak anlamlı bir ilişki belirlenememiştir.

- Öz farkındalık $(\mathrm{r}=, 145 ; \mathrm{p}<0,05)$, pozitif bilgi paylaşım normları $(\mathrm{r}=, 504$; $\mathrm{p}<0,01)$, kimlik $(\mathrm{r}=, 365 ; \mathrm{p}<0,01)$, ortak amaç $(\mathrm{r}=, 509 ; \mathrm{p}<0,01)$, ortak dil $(\mathrm{r}=, 267 ; \mathrm{p}<0,01)$, ile kapalı bilgi paylaşımı arasında pozitif yönlü ve istatistiksel olarak anlamlı bir ilişki belirlenmiştir.

- Diğerkâmlık ( $\mathrm{r}=, 016$; $\mathrm{p}>0,05)$, karşılıklılık $(\mathrm{r}=, 119 ; \mathrm{p}>0,05)$, öz yeterlilik $(r=, 022 ; p>0,05)$, güven ( $r=, 046 ; p>0,05)$, örgütsel ödül $(r=, 090 ; p>0,05)$ ile kapalı bilgi paylaşımı arasında istatistiksel olarak anlamlı bir ilişki belirlenememiştir. 
Bilgi Paylaşımını Etkileyen Faktörlerin Bilgi Paylaşımı Üzerine Etkisi: Bir Alan Araştırması

\begin{tabular}{|c|c|c|c|c|c|c|c|c|c|c|c|c|c|c|}
\hline \multicolumn{15}{|c|}{ Tablo 4. Korelasyon Analizi Tablosu } \\
\hline & 安. & $\dot{\omega} \approx \pi$ & $(1)$ & $(2)$ & $(3)$ & $(4)$ & $(5)$ & (6) & $(7)$ & $(8)$ & (9) & $(10)$ & $(11)$ & $(12)$ \\
\hline (1) & 3,5260 & 1,2391 & 1 & & & & & & & & & & & \\
\hline (2) & 4,0090 & 1,0167 & $\begin{array}{l}, 315^{* *} \\
000\end{array}$ & 1 & & & & & & & & & & \\
\hline (3) & 3,9430 & 9421 & $\begin{array}{l}, 504^{* *} \\
000\end{array}$ & $\begin{array}{l}, 470^{* * *} \\
, 000\end{array}$ & 1 & & & & & & & & & \\
\hline (4) & 3,6350 & 1,0124 & $\begin{array}{l}271^{* *} \\
000\end{array}$ & $\begin{array}{l}397^{* *} \\
, 000\end{array}$ & $\begin{array}{l}, 601^{* *} \\
000\end{array}$ & 1 & & & & & & & & \\
\hline (5) & 3,6352 & 8644 & $\begin{array}{l}457^{* *} \\
000\end{array}$ & $\begin{array}{l}, 494^{* *} \\
, 000\end{array}$ & $\begin{array}{l}\text { 612 } \\
\text {,000 }\end{array}$ & $\begin{array}{l}, 503^{* *} \\
, 000\end{array}$ & 1 & & & & & & & \\
\hline (6) & 3,5350 & 9605 & $\begin{array}{l}389^{* *} \\
000\end{array}$ & $\begin{array}{l}455^{* *} \\
, 000\end{array}$ & $\begin{array}{l}, 503^{* *} \\
, 000\end{array}$ & $\begin{array}{l}483^{* *} \\
000\end{array}$ & $\begin{array}{l}470^{* *} \\
0000\end{array}$ & 1 & & & & & & \\
\hline (7) & 3,9347 & ,8667 & $\begin{array}{l}\text {,027 } \\
\text { 669 }\end{array}$ & $\begin{array}{l}\text {,061 } \\
\text {,336 }\end{array}$ & $\begin{array}{l}-, 016 \\
, 801\end{array}$ & $\begin{array}{l}, 037 \\
, 565\end{array}$ & $\begin{array}{l}, 131^{*} \\
039\end{array}$ & $\begin{array}{l}-, 006 \\
921\end{array}$ & 1 & & & & & \\
\hline (8) & 3,8220 & ,9242 & $\begin{array}{l}, 036 \\
, 575\end{array}$ & $\begin{array}{l}-, 002 \\
, 978\end{array}$ & $\begin{array}{l}-, 077 \\
228\end{array}$ & $\begin{array}{l}-, 056 \\
, 380\end{array}$ & $\begin{array}{l}\text {,030 } \\
\text { 634 }\end{array}$ & $\begin{array}{l}-, 046 \\
468\end{array}$ & $\begin{array}{l}, 295^{* *} \\
, 000\end{array}$ & 1 & & & & \\
\hline (9) & 3,7480 & 1,0192 & $\begin{array}{l}\text {,061 } \\
\text { 334 }\end{array}$ & $\begin{array}{l}-, 018 \\
, 779\end{array}$ & $\begin{array}{l}-, 004 \\
, 947\end{array}$ & $\begin{array}{l}\text {,005 } \\
\text {,939 }\end{array}$ & $\begin{array}{l}\text {,099 } \\
\text {,118 }\end{array}$ & $\begin{array}{l}\text {,039 } \\
\text {,535 }\end{array}$ & $\begin{array}{l}512^{* *} \\
, 000\end{array}$ & $\begin{array}{l}, 590^{* * *} \\
, 000\end{array}$ & 1 & & & \\
\hline (10) & 3,7720 & 1,0886 & $\begin{array}{l}, 039 \\
535\end{array}$ & $\begin{array}{l}-, 062 \\
, 327\end{array}$ & $\begin{array}{l}-, 022 \\
, 735\end{array}$ & $\begin{array}{l}-, 018 \\
, 776\end{array}$ & $\begin{array}{l}\text {,076 } \\
230\end{array}$ & $\begin{array}{l}-, 008 \\
9000\end{array}$ & $\begin{array}{l}, 381^{* *} \\
, 000\end{array}$ & $\begin{array}{l}, 414^{* * *} \\
, 000\end{array}$ & $\begin{array}{l}715^{* *} \\
, 000\end{array}$ & 1 & & \\
\hline (11) & 3,5560 & 1,0690 & $\begin{array}{l}\text {,031 } \\
624\end{array}$ & $\begin{array}{l}125^{*} \\
, 048\end{array}$ & $\begin{array}{l}\text {,006 } \\
923\end{array}$ & $\begin{array}{l}, 024 \\
710\end{array}$ & $\begin{array}{l}128^{*} \\
, 042\end{array}$ & $\begin{array}{l}, 064 \\
, 313\end{array}$ & $\begin{array}{l}, 446^{* *} \\
, 000\end{array}$ & $\begin{array}{l}, 305^{* *} \\
, 000\end{array}$ & $\begin{array}{l}, 407^{* *} \\
, 000\end{array}$ & $\begin{array}{l}\text {, 191** } \\
\text {,002 }\end{array}$ & 1 & \\
\hline (12) & 3,6300 & 9914 & $\begin{array}{l}-, 016 \\
, 800\end{array}$ & $\begin{array}{l}119 \\
\text {,060 }\end{array}$ & $\begin{array}{l}, 022 \\
724\end{array}$ & $\begin{array}{l}, 046 \\
465\end{array}$ & $\begin{array}{l}145^{*} \\
, 022\end{array}$ & $\begin{array}{l}\text {,090 } \\
\text {,158 }\end{array}$ & $\begin{array}{l}, 504^{* *} \\
, 000\end{array}$ & $\begin{array}{l}, 365^{* *} \\
, 000\end{array}$ & $\begin{array}{l}, 509^{* *} \\
, 000\end{array}$ & $\begin{array}{l}, 267^{* *} \\
, 000\end{array}$ & $\begin{array}{l}, 887^{* *} \\
, 000\end{array}$ & 1 \\
\hline
\end{tabular}

** $p<0,01$ : Korelasyon 0,01 düzeyi için anlamlıdır.

${ }^{*} \mathrm{p}<0,05$ : Korelasyon 0,05 düzeyi için anlamlıdır.

1=Diğerkâmlık, 2=Karşılıklılık, 3=Öz yeterlilik, 4=Güven, 5=Öz farkındalık, 6=Örgütsel ödül, 7=Pozitif bilgi paylaşım normları, 8=Kimlik,

$9=$ Ortak amaç, 10=Ortak dil, 11=Açık bilgi paylaşımı, 12=Kapalı bilgi paylaşımı

446 • OPUS @ Uluslararası Toplum Araştırmaları Dergisi 


\section{Regresyon Analizi ve Sonuçlarn}

Çalışmada diğerkâmlık, karşılıklılık, öz yeterlilik, güven, öz farkındalık, örgütsel ödül, pozitif bilgi paylaşım normları, kimlik, ortak amaç, ortak dil faktörlerinin bilgi paylaşımı boyutları olan açık bilgi paylaşımı ve kapalı bilgi paylaşımı üzerindeki etkisi regresyon analizleri aracilığıyla test edilmiştir. Araştırma modelinde yer alan her bir ilişkiyi test etmek için yapılan regresyon analizlerinden elde edilen bulgular aşağıda verilmiştir.

Tablo 5. Bilgi Paylaşımını Etkileyen Faktörlerin Açık Bilgi Paylaşımı Üzerindeki Etkisini Gösteren Çoklu Doğrusal Regresyon Analizi Sonuçları

\begin{tabular}{lcccccc}
\hline Bağımsız Değişken & $\boldsymbol{\beta}$ & $\boldsymbol{T}$ & $\boldsymbol{P}$ & $\boldsymbol{R}^{\mathbf{2}}$ & $\begin{array}{c}\text { Dïzeltilmiş } \\
\boldsymbol{R}^{\mathbf{2}}\end{array}$ & $\boldsymbol{F}$ \\
\hline Diğerkâmlık &,- 033 &,- 503 &, 616 &, 287 &, 257 & $9,597^{*}$ \\
Karşılıklılık &, 100 & 1,481 &, 140 & & & \\
Öz Yeterlilik &,- 050 &,- 598 &, 550 & & & \\
Güven &,- 039 &,- 541 &, 589 & & & \\
Öz Farkındalık &, 066 &, 866 &, 387 & & & \\
Örgütsel Ödül &, 036 &, 517 &, 606 & & & \\
Pozitif Bilgi Paylaşım Normları &, $313^{* * *}$ & 4,838 &, 000 & & & \\
Kimlik &, 097 & 1,415 &, 159 & & & \\
Ortak Amaç &, $333^{* * *}$ & 3,523 &, 001 & & & \\
Ortak Dil &,$- 205^{* *}$ & $-2,608$ &, 010 & & & \\
\hline
\end{tabular}

Bağımlı değişken: Açık Bilgi Paylaşımı,

${ }^{* *} \mathrm{p}<0,05,{ }^{* * *} \mathrm{p}<0,01$

Analizde araştırmanın bağımsız değişkenlerini bilgi paylaşımını etkileyen faktörler (diğerkâmlık, karşılıklılık, öz yeterlilik, güven, öz farkındalık, örgütsel ödül, pozitif bilgi paylaşım normları, kimlik, ortak amaç ve ortak dil) oluşturmaktadır bağımlı değişkenini ise açık bilgi paylaşımı oluşturmaktadır. Tablo 5 'te yer alan düzeltilmiş $\mathrm{R}^{2}$ değeri, 257 olup, bilgi paylaşmını etkileyen faktörler açık bilgi paylaşımını yaklaşık \%25 oranında açıklamaktadır. Bilgi paylaşımını etkilediği düşünülen kavramların açık bilgi paylaşımına olan etkilerini araştırmak için kurulan çalışmanın hipotezleri aşağıda tek tek incelenmiştir;

Araştırmanin hipotezlerini test etmek amacıyla regresyon analiz sonuçlarına göre: 
- Diğerkâmlık faktörünün açık bilgi paylaşımı üzerinde herhangi bir etkiye sahip olmadığı $(\beta=-, 033 ; p>0,05)$ belirlenmiştir. Bu sebeple, "H1" hipotezi reddedilmiştir.

- Karşlıklılık faktörünün açık bilgi paylaşımı üzerinde herhangi bir etkiye sahip olmadığı $(\beta=, 100 ; p>0,05)$ belirlenmiştir. Dolayısıyla, "H3" hipotezi reddedilmiştir.

- Öz yeterlilik faktörünün açık bilgi paylaşımı üzerinde herhangi bir etkiye sahip olmadığı $(\beta=, 050 ; p>0,05)$ belirlenmiştir. Bundan dolayı, "H5" hipotezi reddedilmiştir.

- Güven faktörünün açık bilgi paylaşımı üzerinde herhangi bir etkiye sahip olmadığ1 $(\beta=-, 039 ; \mathrm{p}>0,05)$ belirlenmiştir. Dolayısıyla, " $H 7$ " hipotezi reddedilmiştir.

- Öz farkındalık faktörünün açık bilgi paylaşımı üzerinde herhangi bir etkiye sahip olmadığ $(\beta=, 066 ; p>0,05)$ belirlenmiştir. Bu yüzden, " $H 9$ " hipotezi reddedilmiştir.

- Örgütsel ödül faktörünün açık bilgi paylaşımı üzerinde herhangi bir etkiye sahip olmadığı $(\beta=, 036 ; p>0,05)$ belirlenmiştir. Bulgular ışığın$\mathrm{da}$, "H11" hipotezi reddedilmiştir.

- Pozitif bilgi paylaşım normları faktörünün açık bilgi paylaşımı üzerinde pozitif yönlü ve istatistiksel olarak anlamlı bir etkiye sahip olduğu ( $\beta$ $=, 313$; $\mathrm{p}<0,01$ ) belirlenmiştir ve bu doğrultuda "H13" hipotezi kabul edilmiștir.

- Kimlik faktörünün açık bilgi paylaşımı üzerinde herhangi bir etkiye sahip olmadığ1 ( $\beta=, 097 ; \mathrm{p}>0,05)$ belirlenmiştir. Dolayısıyla, "H15" hipotezi reddedilmiştir.

- Ortak amaç faktörünün açık bilgi paylaşımı üzerinde pozitif yönlü ve istatistiksel olarak anlamlı bir etkiye sahip olduğu $(\beta=, 333 ; p<0,01)$ belirlenmiştir ve bu bulgular ışığında“ "H17" hipotezi kabul edilmiștir.

- Ortak dil faktörünün açık bilgi paylaşımı üzerinde negatif yönlü ve istatistiksel olarak anlamlı bir etkiye sahip olduğu $(\beta=-, 205 ; p<0,05)$ belirlenmiştir. Bu sebeple, "H19" hipotezi reddedilmiştir. 
Tablo 6. Bilgi Paylaşımını Etkileyen Faktörlerin Kapalı Bilgi Paylaşımı Üzerindeki Etkisini Gösteren Çoklu Doğrusal Regresyon Analizi Sonuçları

\begin{tabular}{lcccccc}
\hline Bă̆ımsız Değişken & $\beta$ & $T$ & $\boldsymbol{P}$ & $\boldsymbol{R}^{\mathbf{2}}$ & $\begin{array}{c}\text { Dïzeltilmiş } \\
\boldsymbol{R}^{\mathbf{2}}\end{array}$ & $\boldsymbol{F}$ \\
\hline Diğerkâmlık &,- 123 & $-2,014$ &, 045 &, 390 &, 364 & $15,262^{*}$ \\
Karşılıklılık &, 078 & 1,248 &, 213 & & & \\
Öz Yeterlilik &,- 005 &,- 059 &, 953 & & & \\
Güven &,- 034 &,- 501 &, 617 & & & \\
Öz Farkındalık &, 076 & 1,074 &, 284 & & & \\
Örgütsel Ödül &, 074 & 1,143 &, 254 & & & \\
Pozitif Bilgi Paylaşım Normları &, $322^{* * * *}$ & 5,397 &, 000 & & & \\
Kimlik &, 107 & 1,695 &, 091 & & & \\
Ortak Amaç &, $419^{* * *}$ & 4,805 &, 000 & & & \\
Ortak Dil &,$- 197^{* *}$ & $-2,706$ &, 007 & & & \\
\hline Bağ & & & & &
\end{tabular}

Bağımlı değişken: Kapalı Bilgi Paylaşımı,

${ }^{* *} \mathrm{p}<0,05,{ }^{* * *} \mathrm{p}<0,01$

Tablo 6'da yer alan düzeltilmiş $\mathrm{R}^{2}$ değeri ,364 olup, bilgi paylaşımını etkileyen faktörler kapalı bilgi paylaşımını yaklaşık \%36 oranında açıklamaktadır. Regresyon analizi sonucunda bilgi paylaşımını etkileyen faktörlerin kapalı bilgi paylaşımı üzerinde istatistiksel olarak anlamlı ve pozitif yönlü bir etkiye sahip olduğu belirlenmiştir $(p=, 000)$. Bilgi paylaşımını etkilediği düşünülen kavramların kapalı bilgi paylaşımına olan etkilerini araştırmak için kurulan çalışmanın hipotezleri aşağıda tek tek incelenmiştir;

- Diğerkâmlık faktörünün kapalı bilgi paylaşımı üzerinde negatif yönlü ve istatistiksel olarak anlamlı bir etkiye sahip olduğu $(\beta=-, 123 ; p<0,05)$ belirlenmiştir ve bu doğrultuda " $\mathrm{H} 2$ " hipotezi reddedilmiştir.

- Karşılıklılık faktörünün kapalı bilgi paylaşımı üzerinde herhangi bir etkiye sahip olmadığı $(\beta=, 078 ; \mathrm{p}>0,05)$ belirlenmiştir. Dolayısıyla, " $H 4$ " hipotezi reddedilmiştir.

- Öz yeterlilik faktörünün kapalı bilgi paylaşımı üzerinde herhangi bir etkiye sahip olmadığ $(\beta=, 005 ; p>0,05)$ belirlenmiştir ve bu doğrultuda, "H6" hipotezi reddedilmiştir.

- Güven faktörünün kapalı bilgi paylaşımı üzerinde herhangi bir etkiye sahip olmadığ $(\beta=-, 034 ; \mathrm{p}>0,05)$ belirlenmiştir. Bu sebeple, "H8" hipotezi reddedilmiştir.

- Öz farkındalık faktörünün kapalı bilgi paylaşımı üzerinde herhangi bir etkiye sahip olmadığı $(\beta=, 076 ; p>0,05)$ belirlenmiştir. Dolayısıyla, "H10" hipotezi reddedilmiştir. 
- Örgütsel ödül faktörünün kapalı bilgi paylaşımı üzerinde herhangi bir etkiye sahip olmadığı $(\beta=, 074 ; p>0,05)$ belirlenmiştir ve bulgular ışığında, "H12" hipotezi reddedilmiştir.

- Pozitif bilgi paylaşım normları faktörünün kapalı bilgi paylaşımı üzerinde pozitif yönlü ve istatistiksel olarak anlamlı bir etkiye sahip olduğu $(\beta=, 322 ; \mathrm{p}<0,01)$ belirlenmiştir ve bu doğrultuda " $\underline{H 14 \text { " hipotezi kabul }}$ edilmiștir.

- Kimlik faktörünün kapalı bilgi paylaşımı üzerinde negatif yönlü ve istatistiksel olarak anlamlı bir etkiye sahip olduğu $(\beta=, 107 ; p>0,05)$ belirlenmiştir. Dolayısıyla, "H16" hipotezi reddedilmiştir.

- Ortak amaç faktörünün kapalı bilgi paylaşımı üzerinde pozitif yönlü ve istatistiksel olarak anlamlı bir etkiye sahip olduğu $(\beta=, 419 ; p<0,01)$ belir-

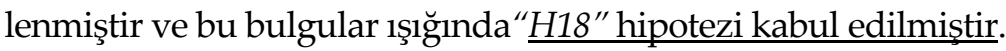

- Ortak dil faktörünün kapalı bilgi paylaşımı üzerinde negatif yönlü ve istatistiksel olarak anlamlı bir etkiye sahip olduğu $(\beta=-, 197 ; p<0,05)$ belirlenmiştir. Dolayısıyla, "H18” hipotezi reddedilmiştir.

\section{Sonuç}

Son yıllarda örgütlerde yaşanan birtakım değişimler ve ilerlemeler bu kurumlarda bilgi, bilgi yönetimi ve bilgi paylaşımı konularına verilen önemin artmasında etkili olmuştur. Çünkü bir kurumda bilginin yönetilmesi ve paylaşılması o kurumun çalışanları için önemli bir unsurdur. Nitekim bilgi paylaşımının sağlandığı kurumlarda çalışanların başarıları artar ve böylece kurumların başarıyı yakalamaları kaçınılmaz olur. Bu noktadan hareketle gerçekleştirilen çalışmada bilgi paylaşımı ve bilgi paylaşımını etkileyen faktörler konuları üzerinde durulmuştur. Araştırmanın amacı bilgi paylaşımını etkileyen faktörlerin bilgi paylaşımı üzerindeki etkisini belirlemektir.

Çalışmada oluşturulan hipotezler SPSS 22.0 istatistik veri analiz progra$\mathrm{m}$ aracılığıyla frekans, korelasyon ve regresyon testleri gibi yöntemler kullanılarak test edilmiştir. Analizler sonucunda elde edilen sonuçlara ve bunlara ilişkin tartışmalara aşağıda yer verilmiştir.

Bilgi paylaşımını etkileyen faktörlerden diğerkâmlığın açık ve kapalı bilgi paylaşımına pozitif yönlü etkisini belirlemek üzere kurulan "H1" ve "H2" hipotezleri regresyon analizleri sonucunda reddedilmiştir. Korelasyon analizi sonucunda ise, diğerkamlık ile açık ve kapalı bilgi paylaşımı arasında 
istatistiksel olarak anlamlı bir ilişki belirlenememiştir. Konuyla ilgili olarak yerli ve yabancı yazın incelendiğinde çalışmamızdaki ile çelişen bulgulara ulaşıldığı görülmüsstür. Yapılan bir araştırmada diğerkamlığın açık ve kapa1 bilgi paylaşımı niyeti üzerinde pozitif etkisi olduğu sonucuna varmışlardır (Hau ve diğerleri, 2013). Başka bir araştırmada ise diğerkamlık davranışı gösteren kişiler, problemlerin oluşmasını önlemeye yönelik davranışlarda bulunmalarına ek olarak iş arkadaşlarını rahatlatıı ve destekleyici davranışlarda da bulundukları belirlenmiştir (Çelik, 2007, s.128). Ayrıca, Lee (2000) yapmış olduğu çalışmasında diğerkâmlığın çalışanların bilgi paylaşımını pozitif etkilediğini tespit etmiştir.

Bilgi paylaşımını etkileyen faktörlerden karşılıklılığın açık ve kapalı bilgi paylaşımına pozitif yönlü etkisini tespit etmek üzere oluşturulan " $H 3$ " ve "H4" hipotezleri regresyon analizi sonucunda reddedilmiştir. Korelasyon analizi sonucunda ise, karşılıklılık ile açık ve kapalı bilgi paylaşımı arasında istatistiksel olarak anlamlı bir ilişki belirlenememiştir. Literatür incelendiğinde elde edilen bu sonuç ile çelişen birtakım çalışmalara rastlamak mümkündür. Hau ve diğg., (2013)'nin yapmış oldukları çalışmalarında karşılıklılığın açık ve kapalı bilgi paylaşımı niyeti üzerinde pozitif bir etkisinin olduğunu belirlemişlerdir. Araştırmacılar, düzenli olarak diğerlerine yardım eden bireylerin yardıma ihtiyacı olduğunda daha hızlı bir şekilde yanıt elde ettiklerini belirtmişlerdir (Rheingold, 2000). Karşllıklılık ile bilgi paylaşımı arasında pozitif yönlü bir ilişkinin olduğunu tespit etmişlerdir.

Bilgi paylaşımını etkileyen faktörlerden öz yeterliliğin açık ve kapalı bilgi paylaşımına pozitif yönlü etkisini tespit etmek üzere kurulan "H5" ve "H6" hipotezleri regresyon analizi sonucunda reddedilmiştir. Korelasyon analizi sonucunda ise, öz yeterlilik ile açık ve kapalı bilgi paylaşımı arasında istatistiksel olarak anlamlı bir ilişki belirlenememiştir. Bu bağlamda çalışmamızın korelasyon analizi sonucunu desteklemeyen teorik kapsamdaki bazı araştırma bulgularının varlığından söz etmek mümkündür. Öz yeterlilik, bilgi paylaşanların sorunları çözme konusunda ve iş verimliliğini arttırma konusunda işletmeye yardımcı olduklarına inandıklarını gösterir. Öz yeterlilik ile bilgi paylaşımı arasında anlamlı bir ilişkinin olduğu belirlenmiştir (Kollock, 1999).

Bilgi paylaşımını etkileyen faktörlerden güvenin açk ve kapalı bilgi paylaşımına pozitif yönlü etkisini tespit etmek üzere oluşturulan " $H 7$ " ve "H8" hipotezleri regresyon analizi sonucunda reddedilmiştir. Korelasyon analizi 
sonucunda ise, güven ile açık ve kapalı bilgi paylaşımı arasında istatistiksel olarak anlamlı bir ilişki belirlenememiştir. Bu bağlamda çalışmamızın korelasyon analizi sonucu teorik ve alan kapsamındaki bazı araştırmaların bulgularıyla kısmen paralellik göstermektedir. Huang ve diğeleri, (2010)'nin yapmış oldukları çalışmalarında güveni etkiye-dayalı güven ve kavramadayalı güven olarak iki boyutta incelemişlerdir ve kavrama-dayalı güvenin açık ve kapalı bilgi paylaşımı niyeti üzerinde negatif etkiye sahip olduğu sonucuna varmışlardır. Yapılan bir diğer çalışmada ise, güven bilgi sistemlerinin grup performansında, entelektüel sermaye değişiminde, örgütsel değer yaratmada, online bilgi işlemde ve sanal topluluklarda önemli bir öncü olarak fark edilmiştir (Ridings, 2002). Çalışma sonucunda güven ile bilgi paylaşımı arasında anlamlı bir ilişki olduğu bulunmuştur. Staples ve Webster (2008)'in çalışmalarının sonuçlarına göre, grup üyelerinin güveni ile bilgi paylaşımı arasında pozitif bir ilişkinin olduğunu belirlemişlerdir.

Bilgi paylaşımını etkileyen faktörlerden öz farkındalığın açık ve kapalı bilgi paylaşımına pozitif yönlü etkisini tespit etmek üzere kurulan " $\mathrm{H9}$ " ve "H10" hipotezleri regresyon analizi sonucunda reddedilmiştir. Korelasyon analizi sonucunda ise, öz farkındalık ile açık bilgi paylaşımı arasında istatistiksel olarak anlamlı bir ilişki belirlenememiştir. Ancak öz farkındalık ile kapalı bilgi paylaşımı arasında istatistiksel olarak anlamlı bir ilişki belirlenmiştir. Ayrıca ulusal ve uluslararası yazın incelendiğinde bu çalışmanın sonuçlarıyla zıtlık gösteren bulgulara ulaşıldığı görülmüştür. Örneğin, O’Dell ve Grayson (1998) çalışanların öz farkındalıklarının bilgi paylaşımı davranışların pozitif yönlü etkilediğini tespit etmiştir.

Bilgi paylaşımını etkileyen faktörlerden örgütsel ödülün açık ve kapalı bilgi paylaşımına pozitif yönlü etkisini belirlemek üzere oluşturulan "H11" ve "H12" hipotezleri regresyon analizi sonucunda reddedilmiştir. Benzer şekilde korelasyon analizi sonucunda da örgütsel ödülün açık ve kapalı bilgi paylaşımı ile istatistiksel olarak anlamlı bir ilişkiye sahip olmadığı belirlenmiştir. Bu konuyla ilgili olarak yapılan bir araştırmada, örgütsel ödül ile organizasyonların bilgi ambarları arasında pozitif ilişki olmakla birlikte, bilgi paylaşanlar bilgilerini zorunda oldukları için değil de istekli oldukları için paylaşmaya eğilim gösterdikleri sonucuna varmışlardır (Kankanhalli ve diğ., 2005, s. 121). Bir diğer araştırma da ise, örgütsel ödülün kapalı bilgi paylaşımı niyeti üzerinde negatif yönlü etkisi olduğunu ancak açı bilgi 
paylaşımı niyeti üzerinde pozitif yönlü etkisi olduğunu bulmuşlardır (Hau ve diğ., 2013).

Bilgi paylaşımını etkileyen faktörlerden pozitif bilgi paylaşım normlarının açık ve kapalı bilgi paylaşımına pozitif yönlü etkisini belirlemek üzere kurulan "H13" ve "H14" hipotezleri regresyon analizi sonucunda desteklenmiştir. Benzer şekilde korelasyon analizi sonucunda da pozitif bilgi paylaşım normlarının açık ve kapalı bilgi paylaşımı ile istatistiksel olarak anlamlı bir ilişkiye sahip olduğu belirlenmiştir. Bu konuyla ilgili olarak yapılan birtakım araştırmalar incelendiğinde çalışmamızdaki ile paralellik gösteren bazı bulgulara ulaşıldığı görülmüştür. Kankanhalli ve diğerleri, (2005)'nin yapmış oldukları çalışmalarında pozitif bilgi paylaşım normları ile bilgi paylaşımı davranışı arasında pozitif yönlü bir ilişkinin olduğu belirlenmiştir.

Bilgi paylaşımını etkileyen faktörlerden kimliğin açık ve kapalı bilgi paylaşımına pozitif yönlü etkisini belirlemek üzere oluşturulan "H15" ve "H16" hipotezleri regresyon analizi sonucunda reddedilmiştir. Ancak korelasyon analizi sonucunda da kimliğin açık ve kapalı bilgi paylaşımı ile istatistiksel olarak anlamlı bir ilişkiye sahip olduğu belirlenmiştir. Bu konuyla ilgili olarak yapılan araştırmalar incelendiğinde Kankanhalli ve diğerleri, (2005)'nin kimlik ile bilgi paylaşımı davranışı arasında pozitif yönlü bir ilişkinin olduğunu belirlemişlerdir.

Bilgi paylaşımını etkileyen faktörlerden ortak amacın açı ve kapalı bilgi paylaşımına pozitif yönlü etkisini belirlemek üzere kurulan "H17" ve "H18" hipotezleri regresyon analizi sonucunda kabul edilmiştir. Benzer şekilde korelasyon analizi sonucunda da ortak amacın açık ve kapalı bilgi paylaşımı ile istatistiksel olarak anlamlı bir ilişkiye sahip olduğu belirlenmiştir. Bu konuyla ilgili olarak yapılan bazı araştırmalar incelendiğinde çalışmamızdaki ile benzerlik gösteren bir takım bulgulara ulaşıldığı görülmüştür. Chiu ve diğ., (2006)'nin çalışmalarında, ortak amaç ile bilgi paylaşımı arasında pozitif yönlü bir ilişkinin olduğunu tespit etmişlerdir. Ayrıca araştırmacılar, ortak amaçlar, ilgiler ve vizyonlar bilgi paylaşımını anlamlı kıldığını ve bununda bilgi paylaşım kalitesini ve miktarını arttırdığını ifade etmişlerdir. Chow (2007) yapmış olduğu çalışmasında ortak amacın çalışanların bilgi paylaşımı niyetleri üzerinde dolaylı bir etkisi olduğu sonucuna ulaşmıştır.

Bilgi paylaşımını etkileyen faktörlerden ortak dilin açık ve kapalı bilgi paylaşımına pozitif yönlü etkisini belirlemek üzere oluşturulan "H19" ve 
" $\mathrm{H} 20$ " hipotezleri regresyon analizi sonucunda reddedilmiştir. Ancak korelasyon analizi sonucunda ortak dilin açık ve kapalı bilgi paylaşımı ile istatistiksel olarak anlamlı bir ilişkiye sahip olduğu belirlenmiştir. Bu konuyla ilgili olarak yapılan araştırmalar incelendiğinde çalışmamızdaki ile çelişen bir takım bulgulara ulaşıldığı görülmüştür. Tamjidyamcholo ve diğerleri, (2013)'nin çalışmalarında ortak dilin bilgi paylaşım sürecini desteklediğini savunmuşlardır (Tamjidyamcholo ve diğ., 2013, s.226).

Genel anlamda araştırmamızdan elde ettiğimiz sonuçlarla ilgili olarak açıklamada bulunmak gerekirse; her ne kadar pozitif bilgi paylaşım normlarının ve ortak amacın açık bilgi paylaşımı ve kapalı bilgi paylaşımına pozitif yönlü etkisini gösteren "H13”, “H14", "H17"ve "H18” hipotezleri desteklenmiş olsa da "H1", "H2", "H3", "H4", "H5", "H6", "H7", “H8”, “H9”, “H10”, “H11", “H12", “H15", “H16”, “H19"ve "H20” hipotezlerinin reddedildiği görülmüştür. Bu sonuçlar ise bilgi paylaşımını etkilediği düşünülen faktörlerin tamamının açık bilgi paylaşımını ve kapalı bilgi paylaşımını etkilemediğini ortaya koymuştur.

Elde edilen sonuçlar değerlendirildiginde, literatürdeki birçok çalışmanın aksine bu çalışmada bilgi paylaşımını etkileyen faktörlerden sadece iki faktörün (pozitif bilgi paylaşım normları ve ortak amaç) bilgi paylaşımı üzerinde pozitif etkileri olduğu belirlenmiştir. Bu sonuç, literatürdeki bilgi paylaşımını etkileyen faktörleri konu alan çalışmalara kısmen destek sağlamıştır. Bu çalışmadan elde edilen sonuçlar çerçevesinde bilgi paylaşımını etkileyen pozitif bilgi paylaşım normlan ve ortak amaç gibi değer ve olguların kamu kurumları tarafından benimsenmesi ve uygulanmasının önemini göstermektedir. Her ne kadar bu çalışmada diğer bilgi paylaşımını etkileyen faktörlerin bilgi paylaşımı üzerinde etkileri bulunmasada, daha önce açıklandığı gibi literatürde bu değişkenlerin bilgi paylaşımı üzerinde pozitif etkilerini bulan çalışmalara rastlanmaktadır. Buradan hareketle, kamu kurumlarının bilgi paylaşımını etkileyen bu faktörlere (diğerkâmlık, karşılıklılık, öz yeterlilik, güven, öz farkındalık, örgütsel ödül, kimlik ve ortak dil) önem ve değer vermeleri gerektiğini söyleyebiliriz. Ayrıca bilgi paylaşımını etkileyen bu faktörlerin dikkatli bir şekilde belirlenmesi, kurum içinde anlaşılması ve uygulanması da bir o kadar önem arz etmektedir. Kurum içi insan kaynakları uygulamaları, sistem ve prosedürlerinin bu çerçevede uyarlanması gibi konularda dikkatle değerlendirilmesi gerekmektedir. Unutulmamalıdır ki, kamu kurumlarında başarılı olmanın yolu bilgiyi üretme, 
işleme, kullanma, saklama, paylaşma yöntemlerini çok iyi bilmeleri ve uygulamalarından geçmektedir.

Elde edilen sonuçlar ve literatürde konu ile ilgili çalışmalar bir bütün olarak değerlendirildiğinde bilgi paylaşımı konusunun önem ve değerinin artarak devam edeceğini ve bu bağlamda bilgi paylaşımını etkileyen faktörlerin öneminin giderek artacağını ayrıca konu ile ilgili araştırmaların teorik ve uygulama bağlamında tüm sektörlerde devam etmesi gerektiğini söyleyebiliriz. Bundan sonraki çalışmaların, farklı kurumlar ve sektörler ve daha geniş kapsamlı ve farklı veri toplama teknik ve analiz yöntemleriyle yapılması bilgi paylaşımını etkileyen faktörlerin dinamiklerini, faydalarını ve sonuçlarını daha iyi anlama bakımından önem taşımaktadır. 
EXTENDED ABSTRACT

\title{
The Effects of Factors Influencing Knowledge Sharing on The Knowledge Sharing: A Field Research
}

\author{
Mihriban Hatunoğlu - Salih Yeşil \\ Kahramanmaraş Sütçü Imam University
}

The existence of information for success is not sufficient alone, but it is also necessary to use it effectively. Effective use of information is achieved through information management. Information sharing, which is one of the elements of information management, includes all the activities shown for the simple access, transfer, and transportation of information between businesses, teams or people (Kalling and Styhre, 2003, p.135). Here, the factors affecting information sharing come to the fore. Information sharing emerges as a process that takes place with the participation of the whole business. It also happens by making the business a place that supports sharing. While creating an information sharing environment, the factors that affect information sharing should be determined well.

In this study, information sharing and affecting factors are emphasized. The aim of the study is to determine the effect of factors affecting information sharing on information sharing. In this context, the research was carried out in a public institution in the province of Kahramanmaraş. Field work was supported by the survey method. In the survey study, scales whose validity and reliability were tested in different previous studies were used. The data obtained were discussed in the context of theory and practice using the SPSS 22.0 statistical data analysis program.

In the literature, the concept of information sharing has been described in different ways by various authors. Connelly and Kelloway (2001, pp. 294301) have defined information sharing as a team work, which consists of actions of changing hands of information and helping others. Information sharing can be defined as all of the processes for ensuring that employees reach the information they need in the fastest and easiest way (Zaim, 2006). 
Information sharing is influenced by all factors that determine people's ties with other people or the business (Erşahan, 2011, p. 266). Unlike other studies, factors affecting the information sharing discussed in this study; concepts of altruism, reciprocity, self-efficacy, trust, self-awareness, organizational reward, positive information sharing norms, identity, common purpose and common language.

ltruism exists when people enjoy helping others and expect no response due to this behavior (Smith, 1981). Reciprocity can be defined as the inability of individuals to continue their actions to help others without knowing when they will get a response in the future or even if they can get a response (Molm et al., 2000, p. 1993). Self-efficacy is the capacity of the individual to organize and properly perform the activities he needs to perform (Ulusoy, 2015, p.62). Trust allows the exchange of ideas and thoughts to continue and proceeds with a perfect exchange of information (Tamjidyamcholo et al., 2013 , p. 225). Self-awareness is the best way for employees to realize their desire to be noticed by their colleagues and bases of information sharing behavior (O'Dell \& Grayson, 1998). If the employee performs successfully in the works he / she has to do, the financial and spiritual gains offered to the company by the organization are called organizational rewards (Sarikaya, 2014, p. 24). Where there are strong group work, cooperation and solidarity norms, people, like other members, will not be bothered to make the necessary effort (Kankanhalli et al., 2005, p. 120). Identity means that a person knows what he has. It is the process that individuals become aware of, just as they try to get to know other people or group members (Bagozzi, 2002, p.11). It incorporates collective goals, collective goals and the wishes or desires of the members of the business. A common goal connects different units of the business or combines resources. Business members who share the same purpose will be more likely to be friendlier in resource exchange or sharing (Tsai \& Ghoshal, 1998). The common language allows participants to understand each other and build a common workspace. In this regard, the common language not only helps to share ideas, but also provides effective communication in those with similar backgrounds or those with similar experiences (Chiu et al., 2006, p. 1878).

The purpose of this study is to determine the effect of factors affecting information sharing on information sharing. The universe size of the research is approximately 400 employees of a public institution operating in Kahra- 
manmaraş province. In the research, questionnaire was used as data collection method. The scales used in the research are taken from previous studies. The surveys were delivered to the employees by hand. On a voluntary basis, the interviewer was distributed and collected by the company. Return was made from approximately 250 employees. The data were analyzed in SPSS (Statistical Package for Social Sciences) using frequency, correlation and regression analysis.

As a result of the reliability analysis applied, Cronbach's Alpha values of altruism, reciprocity, self-efficacy, trust, self-awareness, organizational reward, positive information sharing norms, identity, common purpose, common language, open information sharing and closed information sharing variables vary between 724 and 747 . .

In general, to explain about the results we obtained from our research; Although the "H13", "H14", "H17" and "H18" hypotheses that support the positive information sharing norms and common purpose on open information sharing and closed information sharing are supported, "H1", "H2", "H3

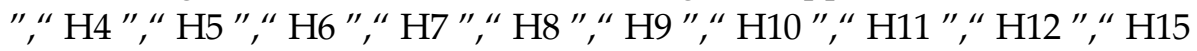
", "H16 ", " H19 " and It was seen that the "H20" hypotheses were rejected. These results revealed that not all factors thought to affect information sharing affect open information sharing and closed information sharing.

When the obtained results are evaluated, unlike many studies in the literature, it was determined that only two factors (positive information sharing norms and common goal) affecting information sharing have positive effects on information sharing in this study. This result partially supported the studies on the factors that affect the sharing of information in the literature. It shows the importance of the adoption and implementation of values and facts such as positive information sharing norms and common purpose that affect information sharing within the framework of the results obtained from this study. Although the factors affecting other information sharing do not have any effect on information sharing in this study, there are studies in literature that find positive effects of these variables on information sharing. From this point of view, we can say that public institutions should attach importance and value to these factors (altruism, reciprocity, self-efficacy, trust, self-awareness, organizational reward, identity and common language) that affect information sharing. In addition, it is equally important to carefully identify, understand and apply these factors that affect informa- 
tion sharing. Careful consideration should be made on issues such as internal human resources practices, adaptation of systems and procedures within this framework. It should not be forgotten that the way to be successful in public institutions is to know and apply the methods of producing, processing, using, storing and sharing information very well.

We can say that the importance and value of the information sharing subject will continue to increase and the importance of the factors affecting the information sharing will increase gradually in the context of the obtained results and the literature, and the researches related to the subject should continue in all sectors in the context of theory and practice. It is important to understand the dynamics, benefits and results of the factors that affect the sharing of information with the help of different institutions and sectors and broader and different data collection techniques and analysis methods.

\section{Kaynakça / References}

Ayazlar, G., (2012). Otel işletmelerinde örgütsel öğrenme ve bilgi paylaşımınn hizmet movasyon performansina etkisi: kuşadası 5 yıldılı otel işletmelerinde bir araştırma. Doktora Tezi, Adnan Menderes Üniversitesi, Sosyal Bilimler Enstitüsü, Aydin.

Aydıntan, B., (2010). Örtülü bilgi paylaşım niyeti üzerinde sosyal sermaye ve denetim merkezi odaklllığının rolü: Hekimlikte bir alan araştırması. Gazi Üniversitesi İktisadi Ve İdari Bilimler Fakültesi Dergisi, 1-26.

Ba, S., Stallaert, J., Ve Whinston, A. B., (2001). Research commentary: Introducing a third dimension in information systems design the case for incentive alignment. Information Systems Research, 12b(3), 225-239.

Bagozzi, R. P., Ve Dholakıa, U. M., (2002). "Intentional Social Action In Virtual Communities", Journal Of Interactive Marketing, 16(2), Ss. 2-21.

Bandura, A., ve Cervone, D., (1986). Differential engagement of self-reactive influences in cognitive motivation. Organizational Behavior And Human Decision Processes, 38(1), 92-113.

Barutçugil, İ., (2002a). Bilgi yönetimi. İstanbul:Kariyer Yayınları, 232.

Barutçugil, İ., (2002b). Bilgi yönetimi nedir? İstanbul: Kariyer Yayıncllk.

Barutçugil, İ., (2004). Stratejik insan kaynakları yönetimi. Kariyer Yayınları.

Becerra, M., Lunnan, R., Ve Huemer, L., (2008). Trustworthiness, risk, and the transfer of tacit and explicit knowledge between alliance partners. Journal Of Management Studies, 45(4), 691-713. 
Chang, H. H., Ve Chuang, S. S., (2011). Social capital and individual motivations on knowledge sharing: Participant involvement as a moderator. Information And Management, 48(1), 9-18.

Chuu, C. M., Hsu, M. H., Ve Wang, E. T., (2006). Understanding knowledge sharing in virtual communities: An integration of social capital and social cognitive theories. Decision Support Systems, 42 (3), 1872-1888.

Cho, T., (2011). Knowledge management capabilities and organizational performance: An investigation into the effects of knowledge infrastructure and processes on organizational performance. Doctoral Dissertation, University Of Illinois, Urbana Champaign.

Chow, W. S., Ve Chan, L. S., (2008). Social network, social trust and shared goals in organizational knowledge sharing. Information And Management, 45b(7), 458-465.

Christensen, P. H., (2005). Facilitating knowledge sharing: A conceptual framework.

Connelly, C. E., Ve Kelloway, K, E., (2001). Predictors of employees' perceptions of knowledge sharing cultures. Leadership And Organization Development Journal, 24(5), 294-301.

Constant, D., Sproull, L., Ve Kiesler, S. (1996). The kindness of strangers: The usefulness of electronic weak ties for technical advice. Organization Science, 7(2), 119-135.

Çelik, M., (2007). Örgüt kültürü ve örgütsel vatandaşlık davramış: Bir uygulama. Doktora Tezi, Atatürk Üniversitesi, Sosyal Bilimler Enstitüsü, Erzurum.

Çetin, M.Ö., (2004). Örgüt kültürü ve örgütsel bağhllk. 1. Baskı, Ankara, Nobel Yayınclik, 90 .

Davenport, T.H., ve Prusak, L., (2001). İs dünyasinda bilgi yönetimi. Rota Yayınları, İstanbul, 270.

Demircan, L., Ve Moltay, A., (1997). Bilgiyi yönetmek. İstanbul:Beta Basım Yayın Dağıtım.

Demircan, M. L., Ve Moltay, C. A., (1997). Bilgiyi yönetmek. Beta Yayıncllk.

Demirel, Y., Ve Seçkin, Z., (2011). Örgütsel adaletin bilgi paylaşımı üzerine etkisi: İlaç sektörü çalışanlarına yönelik bir araştırma. Bilig Dergisi, 56, 99-119.

Gupta, A. K., ve Govindarajan, V., (2000). The social ecology of a knowledge machine. Sloan Management Review, 42(1), 71-80.

Gupta, A. K., Ve Govindarajan, V., (2000). Knowledge management's social dimension: lessons from nucor steel. Mit Sloan Management Review, 42(1), 71.

Gupta, B., Iyer, L. S., Ve Aronson, J. E., (2000). Knowledge management: Practices and challenges. Industrial Management And Data Systems, 100(1), 17-21. 
Hall, H., (2001). Social exchanges for knowledge exchange paper presented at managing knowledge: Conversations and critiques. University Of Leicester Management Centre,. 10-11.

Hau, Y. S., Kım, B., Lee, H., Ve Kım, Y. G., (2013). The effects of individual motivations and social capital on employees' tacit and explicit knowledge sharing intentions. international journal of information management, 33(2), 356-366.

Holste, J. S., Ve Fields, D., (2010). Trust and tacit knowledge sharing and use. Journal Of Knowledge Management, 14(1), 128-140.

Huber, G. P., (1991). Organizational learning: The contributing processes and the literatures. Organization Science, 2(1), 88-115.

Hung, S. Y., Durckkova, A., Lal, H. N., Ve Lin, W. M., (2011). The influence of intrinsic and extrinsic motivation on individuals' knowledge sharing behavior. International Journal Of Human-Computer Studies, 69, 415-427.

Ipe, M., (2003), Knowledge sharing in organizations: A conceptual framework. Human Resource Development Review, 2(4), 337-359.

Işık, M., (2002). Kitle İletişim Teknolojilerine Giriş, 1.Baskı, Eğitim Kitapevi, Ankara.

Işık, M., (2018). Bilgi paylaşımını etkileyen faktörler ve bilgi paylaşım sürecinin yenilikçi iş davranışına etkisi. Uluslararası İktisadi Ve İdari İncelemeler Dergisi, 641656.

İçöz, S., (2014). Afyonkarahisar ilinde görev yapan beden eğitimi ve spor öğretmenlerinin iş tatmini ve bilgi paylaşımı düzeylerinin değerlendirilmesi. Yüksek Lisans Tezi, Dumlupınar Üniversitesi, Sağlık Bilimleri Enstitüsü, Kütahya.

Kallıng, T., Ve Styhre, A., (2003). Knowledge sharing in organizations. Copenhagen Business School Pres, Sweden.

Kankanhall, A., Tan, B. C., Ve Wel, K. K., (2005). Contributing knowledge to electronic knowledge repositories: An empirical investigation. Mis Quarterly, 113-143.

Kayış, A., (2010). Güvenilirlik analizi: Reliability analysis, spss uygulamalı çok değişkenli istatistik uygulamaları. Ed. Ş. Kalaycı, 5. Baskı, Asil Yayın Dağıtım Ltd. Şti, Ankara, 419.

Kollock, P., (1999). The economies of online cooperation, Communities In Cyberspace, 220.

Koza, M., (2008). Bilgi yönetimi: Bilgiyi doğru kullanmak. Kum Saati Yayınları.

Kwok, S. H., Ve Gao, S., (2005). Attitude towards knowledge sharing behavior. Journal Of Computer Information Systems, 46 (2), 45-51.

Laudon, K. C., Ve Laudon, J. P., (2011). Yönetim bilişim sistemleri. Çev. Edi. U. Yozgat Ankara: Nobel Akademik Yayıncllk. 
Lee, C.C., Ve Yang, J., (2000). Knowledge value chain. Journal Of Management Development, 19 (9), 783-794

Lin, H. F., (2007). Knowledge sharing and firm innovation capability: An empirical study. International Journal Of Manpower, 28(3/4), 315-332.

Lin, H. F., Ve Lee, J. N., (2006). Effects of socio-technical factors on organizational intention to encourage knowledge sharing. Management Decision, G. G., 44 (1), 74-88.

Lın, W. B., (2007). Factors affecting the correlation between interactive mechanism of strategic alliance and technological knowledge transfer performance. The Journal Of High Technology Management Research, 17 (2), Ss. 139-155.

Lin, W. B., (2008). The exploration factors of affecting knowledge sharing-the case of Taiwan's high-tech industry. Expert Systems With Applications, 35 (3), 661676.

Molm, L. D., Takahashı, N., Ve Peterson, G., (2000). Risk and trust in social exchange: An experimental test of a classical proposition. American Journal Of Sociology, 105 (5), 1396-1427.

Nemli, H., (2007). Örgüt kültürü ile bilgi paylaşımı arasındaki ilişkiye yönelik biraraştırma. Yüksek Lisans Tezi, Dumlupınar Üniversitesi, İktisadi Ve İdari Bilimler fakültesi, Kütahya.

Nonaka, I., Krogh, G.V., Ichıjo, K., (2002). Bilginin üretimi. Günay, G. (Çev.). Dışbank Kitapları, İstanbul, 16.

Nonaka, I., Ve Takeuchı, H., (1996). The knowledge-creating company: How Japanese companies create the dynamics of innovation. Long Range Planning, 4 (29), 592.

O'dell, C., Ve Grayson, C. J., (1998). If only we knew what we Know: Identification and transfer of internal best practices. California Management Review, 40 (3), 154-174.

Odyakmaz, N., (2000). Bilgi teknolojileri, küreselleşme ve kalkınma. Dış Ticaret Dergisi, 18, 96-113.

Organ, D.W., (1988). Organizational citizenship behavior: The good soldier syndrome. Lexington Books, Lexington, Ma.

Öneren, M., Çiftçi, G. E., Ve Harman. A., (2016). Bilgi paylaşımının yenilikçi davranışa ve örgütsel güvene etkisi üzerine bir araştırma". Akademik Bakış Uluslararası Hakemli Sosyal Bilimler Dergisi, 58, 127-157.

Öztürk, A., (2005). İşletmelerde bilgi yönetimi ve bilgi paylaşımı: Eskişehir İli örneği. Yüksek Lisans Tezi, Dumlupınar Üniversitesi Sosyal Bilimler Enstitüsü, Kütahya, 
Renzl, B., (2008). Trust in management and knowledge sharing: The Mediating Effects Of Fear And Knowledge Documentation. Omega, 36 (2), Ss. 206-220.

Reychav, I., Ve Weisberg, J., (2010). Bridging intention and behavior of knowledge sharing. Journal Of Knowledge Management, 14 (2), 285-300.

Rheingold, H., (2000). The virtual community: Homesteading on the electronic frontier. Mit Press.

Ridıngs, C. M., Gefen, D., Ve Arınze, B., (2002). Some antecedents and effects of trust in virtual communities. The Journal Of Strategic Information Systems, 11 (3-4), 271-295.

Roberts, J., (2000). From know-how to show-how? Questioning the role of information and communication technologies in knowledge transfer. Technology Analysis And Stratagic Management, 12 (4), 429-443.

Sarıkaya, Ö., (2014). Çalışanların örgütsel bağhllk ve iş tatmin düzeylerinin incelenmesi. Yüksek Lisans Tezi, Beykent Üniversitesi, Sosyal Bilimler Enstitüsü, İstanbul.

Schulz, M., (2001). The uncertain relevance of newness: organizational learning and knowledge flows. Academy Of Management Journal, 44(4), 661-681.

Seçer, İ., (2015). Spss ve hsrel ile pratik veri analizi: Analiz ve raporlaştırma. Anı yayınclik.

Seonghee, K., Ve Boryung, J., (2008). An analysis of faculty perceptions: attitudes toward knowledge sharing and collaboration in an academic institution. Library And Information Science Research, 30(4), 282-290.

Smith, D. H., (1981). Altruism, volunteers, and volunteerism. Journal Of Voluntary Action Research, 10 (1), 21-36.

Smith, E.A., (2001). The role of tacit and explicit knowledge in the workplace. Journal Of Knowledge Management, 5(4), 311-321.

Staples, D. S., Ve Webster, J., (2008). Exploring the effects of trust, task interdependence and virtualness on knowledge sharing in teams. Information Systems Journal, 18 (6), 617-640.

Tamjidyamcholo, A., Baba, M. S. B., Tamjıd, H., Ve Gholıpour, R., (2013). Information security-professional perceptions of knowledge-sharing intention under self-efficacy, trust, reciprocity, and shared-language. Computers And Education, 68, 223-232.

Tsal, W., Ve Ghoshal, S., (1998). Social capital and value creation: The role of intrafirm networks. Academy Of Management Journal, 41(4), 464-476. 
Ünal, Z., (2003). Öğretmenlerde İş doyumu ve örgütsel vatandaşllk. Yayınlanmamış Yüksek Lisans Tezi, Afyon Kocatepe Üniversitesi, Sosyal Bilimler Enstitüsü, Afyon.

Vaas, L. (1999). Brainstorming: Before opening the floodgates to new $\mathrm{km}$ technologies, it managers should make sure users are ready, willing and able tos hare what information they know. Pcweek, 16(22), 1-65.

Wang, Z., Ve Wang, N., (2012). Knowledge sharing, innovation and firm performance. Expert Systems With Applications, 39(10), 8899-8908.

Wasko, M. M., Ve Faraj, S., (2005). Why should 1 share? examining social capital and knowledge contribution in electronic networks of practices. Mis Quarterly, 29, 35-57.

Wood, R., Ve Bandura, A., (1989). Social cognitive theory of organizational management. Academy Of Management Review, 14 (3), 361-384.

Xınyan, Z., Ve Xın, Z., (2006). Moderating effects of organizational justice to knowledge-based psychological ownership and knowledge sharing. In Proceedings Of The 8th International Conference On Innovation And Management, 875-879.

Yaghı, K., Barakat, S., Alfawaer, Z. M., Shkokanı, M., Ve Nassuora, A., (2011). Knowledge sharing degree among the undergraduate students: A case study at applied science private university. International Journal Of Academic Research, 3(1), 20-24.

Yıldız, G., Yılmazer, A., (2005). Bilgi işlem hizmetleri için dış kaynak kullanımı (Outsourcing): Adapazarı Büyükşehir Belediyesi örneği. 4. Ulusal Bilgi, Ekonomi Ve Yönetim Kongresi, 15-16 Eylül, Sakarya, 837-854.

Zaim, H., (2006). Bilgi Yönetimi Süreçleri, bilgi çă̆̆, bilgi yönetimi ve bilgi sistemleri.

\section{Kaynakça Bilgisi / Citation Information}

Hatunoğlu, M. ve Yeşil, S. (2020). Bilgi Paylaşımını Etkileyen Faktörlerin Bilgi Paylaşımı Üzerine Etkisi: Bir Alan Araştırması. OPUSUluslararası Toplum Araştırmaları Dergisi, 16(27), 424-464. DOI: 10.26466/opus.632192 